NOTICE

This report was prepared as an account of work sponsored by the United States Government. Neither the United States nor the United States Energy Research and Development Administration, nor any of their employees, nor any of their contractòrs, subcontractors, or their employees, makes any warranty, express or implied, or assumes any legal liability or responsibility for the accuracy, completeness or usefulness of any information, apparatus, product or process disclosed, or represents that its use would not infringe privately owned rights.

\title{
PRELIMINARY EDITION
}

REPORT NO。 RN-DR -0019

\section{REON/SACRAMENTO MANAGEMENT PLAN}

APRIL 1964
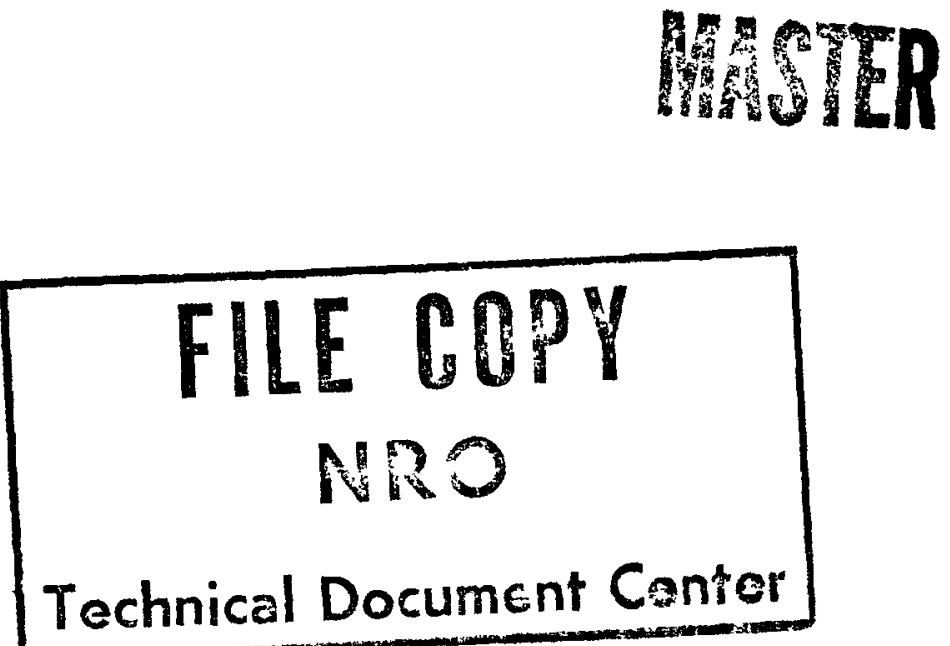


\section{DISCLAIMER}

This report was prepared as an account of work sponsored by an agency of the United States Government. Neither the United States Government nor any agency Thereof, nor any of their employees, makes any warranty, express or implied, or assumes any legal liability or responsibility for the accuracy, completeness, or usefulness of any information, apparatus, product, or process disclosed, or represents that its use would not infringe privately owned rights. Reference herein to any specific commercial product, process, or service by trade name, trademark, manufacturer, or otherwise does not necessarily constitute or imply its endorsement, recommendation, or favoring by the United States Government or any agency thereof. The views and opinions of authors expressed herein do not necessarily state or reflect those of the United States Government or any agency thereof. 


\section{DISCLAIMER}

Portions of this document may be illegible in electronic image products. Images are produced from the best available original document. 


\section{TABIS or COWTEMHS}

I. Irworuction

A. G GIERAT

B. THS MERVA THETIE

c. WEST OP THE MHAR EMTIS

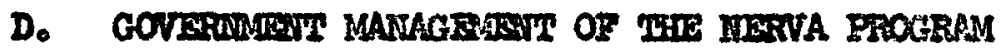

E. THE COHLRACTOR ORGATIEATIOT

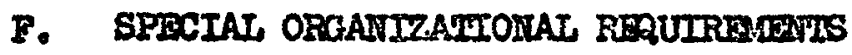

II. MAIIPONER

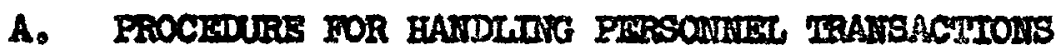

II. OROAUTramion

A. GEIRTAL

B. PRHCIPAI FUCHONS

c. TASK ORGAUIRAIICO

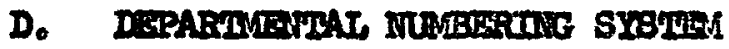

IV. FACIIIIIES

A. Grimar

B. OFFICE SPACE

c. SPECIAI ROCWS

D. SPBCIAT AREAS

v. FIscit

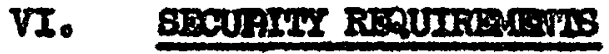

A. GrukzaI

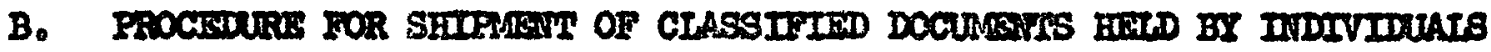

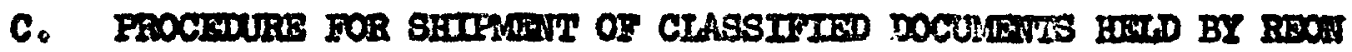
WrGEITCAT IHPOBMATIOA CZITDER

D. RBON COWHROL SRAMTOON

Bo COUPANY CONILOLITED ACCLSS AREA

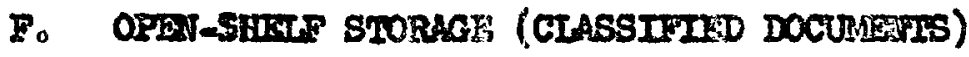

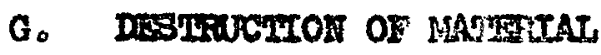


Table of Contents (Cons, d)

H. DOCURIEIT ACCOUNTABIIITYY

I. VISIT CLBARAYCE

J. COURIIKR AUTHORIZATTON

K. EMPIOYIEE CLEARAHCES

I. TRANSFFR OF SECURITY CLEARAUCES

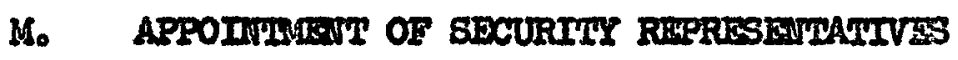

11. CLASSIFICATION OF GROUP ASSIGMUMNT OFFICERS

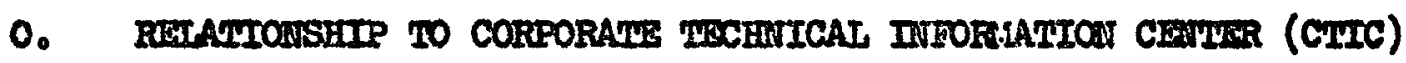

VII. COMRUIICAIIONS 


\section{IISTS OF PABLISS}

I. Ienpower Sumary Unconf1rmed by Budget

II. REON and MO Direct and Indirect Manpower Ratios

III. Facillties Capital Expenditure Estimete

IV. Sacramento Space Requirements for Office and

Special Rooms

V. RBow Classifled Information Log - June 1963

VI. Departmental Security Representatives

VII. Classification and Group Assignment Officers 
F1G. 1 Ferva Flight Test Eagine Nockup

FIg. 2 Hot Bleed Cycle Flow Schematic

FIg. 3 Rift Stage

Fig. 4 E-MAD Builaing

MB. 5 Pngine Transport - Installation Systen

Flg. 6 Test Cell A

Fig. 7 Englne Test stand 10. 1

Fig. 8 Huclear Rocket Procram Organization

Fig. 9 REOR Organization

PiB. 10 Jaria Nanpower vs Time

Fig. 11 Formal Offer Memo

FIg. 12 Program Manager Organization

FI. 13 NIO Organization

FIG. 14 Administration Maneger Organigation 


\section{IIST OR APPEIDICES}

A. Special Boom Iayouts

B. Controls Iaboratory Equipnent

C. Procedure for moving Documents and Flies to Sscramento or IRDB

D. Securlty Control Procedures - Rron Restricted Aree

B. Access to Brad Area

F. Boxing and Iransfer of Classifled Docunents to Sacranento and Inms

Q. Curc Nems

H. BPI C-08-18-0 
I. INIRODUCTION

A. GERERAT,

With the inminent relocation of the REON organization to the Sacremento Plant, there is a need for a definitive document describing the reaulting organization, its function, its interfaces with other sacramento functions, its product, its custower, and other generel planning data for the Information and guidance of all concermed. It is the purpose of this report to fulfill this need. General background naterial is provided followed by detailed descriptions of manpower requirements, orgenization, contract task and sub-task manegement, facllity fiscal requirements and fiscal considerations, security, safety and etc.

\section{B. THE RERVA EHGINE}

It is probably most logical to begin the background discussion with a definition of the product, nomely, nuclear rocket engines.

To place this discussion in its chronological context, some history in this vital new fleld must be revieved. The first recorded mention of American nuclear rocket propulsion was made in 1944, when some Los Alawos Sclentific Laboratory (IASL) personnel speculated about a broadrange of potential application of nuclear energy to propuleion. In 1946, a report was published concerning the application of a heat exchanger reactor to rociset propulsion. At that time, there wa considerable aclentific interest in the possibility of combining the tremendous potential of nuclear energy with the then-newly-exploited propulsion system concept of rocketry. Analysis and conceptual design studies vere conducted by several organizations. Do opecific hardware developments were ordered, and the application of nuclear energy to propulsion was confined to the IIfPA (Iuclear fherey for the Propulsion of Alrcraft) project, the forernmer of the AlP (Alrcraft Iuclear Propulsion) program. In the early $1950^{\prime} \mathrm{s}$ interest vas ogain evidenced in the nuclear rocket concept. This interest developed in several locations almost simultaneously, with enthusiasm kindled at Aerojet-General Curporation and elsewhere by the late Dr. Theodore Von Karman, Aerojet's founder and Chairman of 1ts Technical Advisory Board. Iargely because of this renewed Iropetus, the Atomic Energy Comolssion (ABC) directed IASL and the University of C alifornia Fadiation Laboratory (UCRL - Ifverwore, Callfornia) to otudy the probless of applying nuclear power to rocket propuloion. At that time, the UCRL group followed an epproach which centered around the use of solid graphite reactors, with hydrogen as a propellant, while the LAsI program included consideration of ammonia or methane as propeliants. In 1955, the United 8tates Air Force became vitally interested in the propulision potential offered by nuclear. rocketry. The joint Atomic Bnergy Combission-Inited States Air Force ROVER program was formaliy initiated, with the ABC baving its traditional cognizance over reactor development and testing and the Air Force havinc reopons1bility for non-nuclear engine courgonent and subsystem development and launch vehicle applications. In 1957, a specific ROVER reactor developwent approach was eelected, marking the beginning of the Kiw1 reactor development program. 
The AEC decided to proceed with the fabrication and testing of research reactors using uranium-loaded, graphite fuel elements to heat hydrogen to temperature useful for rocket propulsion. The developwent responsibility was assigned to LASL, and the UCRL group was directed to devote their propulsion reactor efforts to the ramjet application. In 1958, responsibility for developing the non-nuclear engine and vehicles was transferred to the newly-forned National Aeronavitic and Space Adrinistration (IIASA). In 1960, the joint ADC-RASA Space Miclear Propuloion Orfice (SRPO) was orgenized, with Its manager, Mr. Harold B. Finger, reporting to both $A B C$ and IIASA for the national nuclear rocket program.

In the fall of 1960 , the Kiwi program reaklts were so encouraging and the forecasts were so positive and confldent thet SNPO belleved that an industrial engine contractor should be selected to direct and control, under SAPO guidance, the development of a Ilight reactor (based on the IASI-KiwI technology and conflguration) and the non-nucleer engine components and subsystems, and to integrate these into a useful and reliable flight propulsion system. Competitive proposale rere prepared and evaluated in the spring of 1961. In July 1961, the NERVA (Nuclear Ingine for Roclet Vehicle Application) contract was awarded to the Aerojet-General Corporation. At the same time, the Goverament selected the Westinghouse Astronuclear Laboratory as a principal subcontractor for developing the plight reactor and certain other nuclear aspects of the engine development program. Also in 1961, the Ahuclear Vehicle Projects Office (IVPO) was organized within MASA at the Marshall Space Flight Center in Huntsvilie, Alabama, to provide technical direction for the development of the RIFI (Reactor-In-Filight-Test) stage, which would serve as the flight test vehicle for the nuclear engine. The Lockheed Missiles and Space Company was the successful bidder for this program, and the RIrT contract was signed in May 1062.

The MERVA engine development is besed on the solld core, heat exchanger reactor concept, selected by IASL for the Kiwl reactor development program. While other reactor concepts have been suggested and analyzed, the ABC belleved that the I1rst propulsion system development should be based on the signiflcant body of thought and technical data availoble regarding this concept. Although there are some obvious limitations to the solid-core concept, its selection was Judged the most logical approach to the early demonstration of the feasiblilty of nuclear rociket propulsion. The propellant or working fluid chosen to extract the energy from the reactor exerts a significant influence upon reactor and engine design. Because rocket specific imgulse is a d rect function of the root of gas temperature divided by molecular weight, other things being equal, high gas temperature and low molecular welght are desirable. Hydrogen was the logical propellant selection.

As a result of the renewed interest in nuclear rocket propulsion in the early $1950^{\prime} \mathrm{s}$, the ABC selected a speciflc rec.ctor development approach in 1957 and ordered IASL to proceed with the fabrication and testing of research reactors. Before this, IASI had inveatigated graphite materials because these waterials were very high teuperature atructural materials for reactor fuel elements. With the responstbility fox the reactor assigned to it, IASL selected a developrnent approach for early demonstration of feasibility. 
The IASL approach was also stroncly influenced by the difficulty of simulatIng sowe of the reactor environmental conditions rithout actually operating a reactor at a high power level. Hence, in the Kiwl developisent prograsi, there was considerable component testine followed quite early by tests of complete reactors.

Two series of Kiwl tests, were scheduled at the beginning of the development, in accordance with the gutdeline for establishing overall feasibility as soon as practicable. The first series, the Kiwi-A series, was conducted using gaseous hydrogen and was planned principaliy as a fuel eleroent developuent test. The Kiwi-A configurations had somewhat of a "battleship" nature and incorporated nany features for facllitating and expediting the teet program, but these features would subsequently have to be modified or eliminated before a flight configuration could be established. Further, the decision to proceed with the Kiwi-A series using gaseous hydrogen postponed the necessity of developing and procuring liquid bydrogen pumping equipment. The flrst Kiwl (KivL-A) reactor test was conducted at Jackass Flats, Nevada, In July 1959, and was operated at rated power and temperature for several winutes. The Kiwl-A $\mathrm{A}^{1}$ was tested in July 1960. The Kiw1-A had the sarse general external configuration as the Kiwi-A but had a revised core design. The thind test in the Kiwi-A series (Kiwi-A3) was conducted during October 1960, with the core instrumented to provide data to verify some disfrepancies observed between predicted and actual operation during the Kiw1-A test. These three tests completed the KIWI-A program.

The overall Kiwl-A results were very encouraging. Some problems were discovered in the experiments but many of these vere vell understood and had been predicted in advance. Personnel at IASL belleved that the remaining problems could be solved satisfactorily in the subsequent Kiwl-B liquid hydrogen serles. Largely because of the successful Kiwi-A series and the enthusiastic forecasts made for the Kiwl-B serles, the Government believed that It was timely to select an industrial engine contractor to be responsible for the developwent of the nuclear rocket engine system. At this time, the Kiwi-B serles of reactors was being designed, and parallel approaches were being used in some areas to solve sowe of the problens. For exminie, more than one type of core support was planned for this series of reactors. The Kiwl-B tests were scheduled to begin in the autumn of 1961, and to extend through the following year. This Kiwl-B program actually got under way late in 1961 and eventualiy required more tiwe than had been scheduled. Sone of the initial delay was caused by problens associated with the conversion of the test cell to handle liquid hydrogen. The first Kiwi-B tesi was conducted in December 1961, and gaseous hydrogen was enployed as the propellant to provide a checkout of the new KiwI-B basic design. In Septeraber 1962, the second KIWI-B reactor test was conducted, and in Novewber $196 \%$, the third. During these teats, the reactor core and its support falled.

The tests could hardly be considered to be successiul or to serve as a basis for committing a complete engine development effort. The mechanisin of fallure was not understood, and after the thind Kivi reactor test, thcre were several, apparently equally valid, postulations of the reason for fallure. 
It was declded that, before the next power teat, extensive reactor component development testing and complete reactor core cold flow and vibration testIng would be completed. The first of the cold flow experiments was conducted in Hay 1963. As a result of this test, the mechanism of core fallure was at least testatively identifled so being associated with vibrational dynamics. Hence, it was possible to Incorporate certain design changes into the reactor configuration to ensure that subsequent power tests would be successful. More cold flow tests and an extensive series of vibration tests have now been completed. As a result of the reactor tests to date, much has been learned, and problems identifled as serious developwent obstacles at the outset of the program have been solved satisfactorlly. The physical properties of graphite are reasonably well underatood and have been verlfled by testing. Methods have evolved for satiafactorly fabrlcating the graphite fuel elements, and tecimiques have been developed for their operation in a hydrogen environment. The problems of control during start-up and operation have apparently been solved. In fact, durlng the last Kiwl power test, when there were extreme variations in reactivity and other parameters, the controls performed satisfactorliy under much more severe conditions than would ever be expected in the engine during development test or flight. The structural integrity of the reactor core is the principal remaining reactor development objective to be achieved.

As indicated, the results of the KinL- $\mathbb{C}$ serles of reactor test were so encouraging and the forecasts for the Kiv1-B serles of tests were so enthusiastic that the contract for the engine development wasamaried to AerojetCeneral Corporation in July 1961. Hestinghouse Astronuclear Iaboratory was selected as principal subcontractor with responsibility for developing the Iight reactor based on the IASI/KIwI technology and conflguration.

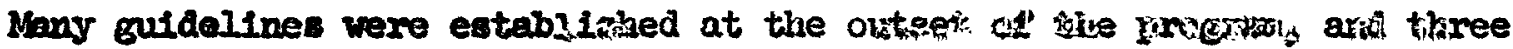
of these are worth mentloning to provide better underatanding of som of the develogments and events that have occurred since the initiation of this program.

The flight reactor design was to be based on IASI/KSWI technology and configuration, and the industrial tean was to wake only those changes in the mechanical design that were necessary to ensure that the reactor could perform In the space environment.

The second slenificint ground mule concerned the development of the non-nuclear engine corponents and subsysterns and required that no large scale Procurement or development of these components or subsyatems be effected until a reactor configuration vas tested successtully and approved for incor. poration in the encine. Ine developanent that was perfuitted had to be related to congonents with long lead tines or that have critical or unknown characterLatics from the standpoint of engine or reactor operation or testing. An example of this approach 28 the development of the turbopump for use in the engine propellant feed system, which is proceeding, while less attention is being devoted to such Iteis as the thrust structures, the gimbel, and roll control. Because of the continuing reactor mechantcal design problem, this Eround rule reming in force. 
The third significant ground rule concerned the overall goels and objectives of the UFFA development. The ultimate goal of this program is the demonstration that a nuclear rocket propulsion system will perform safely and reliably in the space environment. While directed studies of the application of WWAVA class engines to specific missions of interest are being conducted, this, initial INERVA program goal remains as stated.

In mid-Deceriber 1963, MERVA program redirections were announced. The RIII (Reactor-In-FIIght-Ieet) Progrom, to demonotrate that a nuclear rocket will, in fact, perform safely and reliably in the space enviroment, was cancelled. All NWRVA angine vork devoted to Plight syotems was deferred and the stated objectives of the IWTVA procerem were restricted to include ground testing and static test demonstration only. According to the official MABA new reloase published on 24 December 19638

". - AEC/WASA wIIl concentrate on ground reactor and experimental engine research and developwent and tests with particuler emphasis on arialyzing and understanding power levels, temperatures, operating life and the problems of frequent and reliable restarts. Work toward the develogment of the IIight syotem is deferred unt1l the technology learned from the KiwI and IWWVA project has been satisfactortily established."

". - The mafor effort will be on reactor engincering and on other essential subsystems necessary to the creation and operation of an experimental nuclear propulaton engine. Trose elements essential to the ground test progrem vill be included. This revised project will require a lover level of funding but contemplates undertaking an eventual flight system develogment."

Thas the formal developwent program is now defined to consist of a number of reactor tests to be followed by static test of ground test engine configurations.

The first six months of the IILRVA progran, Fhase I, lasted from July 1961 through January 1962. This initial effort was devoted largely to two principal activities. The first major effort cuncerned the preliminary desion of the IHEIVA Plight test engine. The second effort concerned the complete congine develofment progrm plan. During this period, some non-nuclear engine components were bullt and tested, and certain other activities were conducted, but the preifminary design and the program plan were the chlef results. During Phose I, a full-ncale mockup of the wirkA IIIght test engine was constructed. A photograph of this mockup is shown in Fleure 1. The Plight teat engine is epproxirately $22-1 / 2$ feet long from the engine-vehicle interface to the exit plane of the exhaust nozzle. It is appraximately 56 inches in diameterat the pressure vessel, and the waximum envelope is approximately 8 feet across the pressurization spheres. The NGRVA engine consists of several major subsystems: the propellant feed system (including the turbopump and required valves and lines); the nuclear subsystem (including the reactor, the reflector, and the shield); the thrust chamber assembly (including 
thrust structurea, pressure vessel, gimbal for thist vector control, and the main engine exhaust nozzle): the engine control syoten; and the pneumatic systeri.

The NGRVA onclne operates on the so-called bot bleed cycle principle, which derives its name from the position along the propellant feed system flow path, and hence tersperature, at which hydrogen is extracted to provide the turbopum worising fluld. A flow scheratic is show in Figure 2. Ilquid hydrogen propellant from the velaicle tank enters the engine through the mein tank shutorf valve, Ilows through the purm, 1s ducted to the cooling passages of the main thrust nozzle where it regeneratively cools the nozzle, passes up inside the presaure vessel through the reflector and shleld, passes through the reactor core where it $\therefore$ s heated to a very high termperature, and is finally discharged through the main exhaust nozkle producing the engine thrust. The hot bleed cycle extracts a mall percentage of the propellant flow at the reactor extt. This bleed flow 18 cooled by some relatively cool hydrogen from the reactor core inlet pleism. Thls bleed flow then enters the turbine as workeng fluld and the turbine exhaust is discharged overboard through autable nozzles to provide residual thrust recovery and vehicle roll control.

Altbough the potential of nuclear rocket propulsion in terws of vehicle periunsunce is certainly vast, these gains are not achieved without cortain complications that have not been previously encountered in rocket development and operation. One of the most signifleant of thess unique eavironments is radiation, which creates lone list of effects and influences raninging from the behavior of materials in the combined radiation-cryogenic enviromment to the requirements for the remote engine assembly and disassembly techniques and the general hazards problem. Also, the restdual radiation existing after engine shutdorn creates the many problems associated with the cooldown requirement. The long durations of operation which cen be expected with this new propulsion system place new and unusual requirements on rocket rotating machinery as well as the lifetime of the reactor core in its unlque enviromient.

At the outset, the IFHVA progran was defined to demonstrate the feasibillty of using nuclear roclets. The demonstration procrar will involve Beveral ballistic Illghts from Cape Canaverel, boosted by the sAuUfa V Iaunch vehicle. As envisaged in the RTry program, this vehicle will be 33 feet in diemeter and will welght much more than 100,000 pounds when fully loaded. Sizes can be appreciated by noting that the diminutive engine, as it appears in Figure 3, is over two stores high.

The userulness of IEFVA is not planned to end with the balliatic feasibllity demonotration. An underlying philosophy in the development of RIFI and WERVA is that they ultimately be capable of performing useful operational missions in opace. Accorilngly, nuijerous application studies are being made of the MriVA engine. These studies cover lunar operations of several forros and hellocentric transfer orbits for "deep space probls," manned exploration, and parabolic and hyperbolic solar system escape trajectorles. 


\section{c. TLET OF THE IERTIA ESTINE}

The cholce of an approprlate teat alto for the reactors of the Kiwi program was a sigaificant consideration because of the dangers of a possible excursion within the reactor and because the facility should be kept reasonobly simple by releasing the exhaust plume into the open atmosphere. The AEC and IASL have used two principal teat altes for many years - one in the Pacific, and the second at Jackass Flats, Nevada, approximately 90 wiles north and west of Ias Vegas. Early estimates that the release of the exhaust plume in the Hevada sky pas permissible vere confirmed by testing. Testing of the KCWI reactors has been particularly successful as regards the release of redicactivity at the test ilte. Largely for this reason, the same site was chosen for the engine test.

The unique radiation enviroments present scme new complications in conducting the develogment test progran. The reactor and the non-nuclear engine subsystems vill be assembled into the complete teat ensine in the Ingline kaintenance, Assembly, and Disassembly buIJ ding (E-MAD) at IRDS. A cutarny view of this sulitifing is show in Figure 4. When assembled, the encine is placed on the engine installation vehicle for transportation and Installation into the test stand, wich is locatec approximately two miles from the E-MAD building. This transport-installation system is shown in Figure 5. The Ingine Inotellation Vehicle (EIV) is essentially a railway flat car with appropriate superstructure to support and transport the engine. The ohfelded control car bouses two men who will bave control over the entire englne tranport and test stand inotallation sequence. Hotive power is provided by the prime mover, also shown in the figure. Following the engine teats, the engine 18 renotely disengeged rom the test otand, attached to tho HIV, and returned to the E-MAD hulldind where it is remotely disassembled for post-moxtem inspectivn. The engine is dieassembled into its major subsyatems in the wain bey of the E-MAD bullaing, and amall aatellite cells located aroumd the periphery of the mein bay are used for the discssembly and post-inoxtem inspoction of individual subsyntems and componente. The overhead positioning system, the vall-mounted handiling system, the typical floor-mounted fixtures are shown in the cutasay vies of the E-MAD butlding. Ground was broken for this faclilty at IRDS in August 1962. About 2-1/2 years will be required to complete the construction and activation of the facility.

Test Cells $A$ and $C$ were also built at inRos to meet the requirements of the Kiwl reactor test program. These tro test cells are simllar, and one is shown in Figure 6. Iest Cell A will also be used to accommodate the development test of the IrerVA IIIght reactor. The Reactor Naintenance Assembly, and disassewbly bufliding (R-MAD) was also buflt for the KIWI program and will be used by Wrava during the fileht reactor test serles. 
Ground was broken for the first nuclear rocket engine test otand (EMS-1) In June 1961, one month before the award of the IrHVA contract. Design work had preceded the consiruction by approximately ten months to a year. An artist's concept of the completed facility is shown in Figure 7. The hydrogen storage facilities, the hydrogen run tank and its shielding, the rail-mounted side shields, and the engine exhaust duct are also show in the figure. The lacillty is approximately 140 feet high from the deck surface to the top of the run tanis superetrusture, and the vault containing the exheust duct is approximately 55 feet deepe The test stand civil worlis are largely completed. However, the sacility Instrumentation, control, and nuclear rocket exhaust system must ba installed and checked before the racility can be completely activated for the first engine development test.

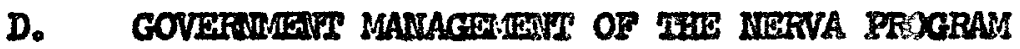

Hisving defined the IFRVA engine, its istory, status, and capabilities, It is next signiflcant to expmine the orgenization remponalble for the national nuclear roclset effort. As indicated previously, tbe Space Inuclear Propulsion Orfice (SMrO) was created in 1960 under the provision of an Interagency Hemorandum of Understanding betireen the Atoulc Bnergy Conmission and the National Aeronautics and Space Administration.

The manager of SITO, Mr. Barold B. Finger, seports to both the AIC and INASA for the national muclear rocket effort. Within the AEC, the chamel is through the Director, Divia1on of Reactor Developesent, and within MASA, It is through the Director, Offlce of Advanced Fesearch and Tecbnology. The Space Mhclear Propulaion OffIce Headquartere in Hashington (SWPO-U) has three field extensions: The Cleveland extension (BMPO-C), located at the Lewis Besearch Center of IASA, is responsible for the technical direction of the engine development programs the Albuquerque extension (SMFO-A) provides certain liaison fumctions with IASI and the Nevads extension (BMPO-N) provides cognizance of the development test activities at the Iuclear Rociset Develogwent Stationf As shown, lir. Finger also has additional responsibilIties within INASA as Director of muclear Systems in the Offlce of Advanced Research and Technology. In this cepacity, he provided program direction to the Ihaclear Vehicle Projects Office at the Iarehall Space Flight Center. Ur. Bobert W. Schroeder 18 Chief of SMPO-C and IIr. Bob P. Helgeson is Chief of SifO-I. The govermuent organization 18 ahown in Figure 8.

The NHANA program is a new experience for Aarojet in that it deale with a relatively new govermient organization which has inherited policies, procedures, and attitudes from 1ts parents while at the same time attengting to develop a character of its own. There is an extensive detalled monitoring function belng performed by SIIPO personnel, perheps nore day-to-day probing than Aerojet has ever experienced on any development progrens. 
There is probably an additional point to be mede when describing the customer. With very few exceptions, the \$sco personnel have a research laboratory or academic background and there is an irsportant difference in epproech to a major development progran between the SirPo and the Aerojet personnel. The basic differences between the contractor and government personnel is concerned largely with the technologlcal approach to be employed in achieving system development objectives. There Is ons body of thought which recommends path of extensive analyses, deliberate laboratory research, exhaustlve component research and development and ultimately culminating in subsystems and total system integration and test. The majority of the government personnel engaged in the IrARA technical direction and ronitoring activities belong to this school. The other principal approsch to system development is the one that is typiculy errployed by Industry and has been utilized in every previous major development program, 80 far as we lnow. Industry in general, in the conduct of develogment efforts, has followed a course walch consists of an initial analysis of the development objectives to be ackieved within a given time perfod together with a postulation of the most probable route leading to the stated objectives. In certain cases, suboriinate and sometimes parallel backup efforts are included. Industry, in general, tends to build experimental hardwere as soon as possible, to test this bardware for adequacy, to utilize the test results in systems analyses to predict the results of design rodification to build new hardware, to test etc. Thus a program is character-1zed by the iterative sequence of design, build, test, redesign, butld, test, until the development objectives bave been achieved. FEON supports this empirical approach. The government personnel directing and monitoring our program are specifically research-oriented and expect to ser a great deal more analytical work before design, bartware fabrication and test are initiated. On the other hand, the contractor pereonnel are anxious to proceed with axperimental veriflcations of concepts and therefore initiate desion, fabrication and test at an earlier point in time than would our government counterparts. Th1s is not to mean that these differences in approsch are detrimental to the best interests of a development prograx. In fact, the blend of the two way well yield a rational middle course representing the most effective method of accomplishing objectives. Nelther of the tro approaches is bad, merely different, but it is slgaificant to point out that they do create "people problems," in our relationship with our customer.

\section{THE COWIRACALOR ORCANIZAUIOA}

Then the IFRVA prime contract was awarded to Aerojet-General in July of 1961, the Corporation established a special program mansement of at its Azusa, California, plant to eserclse overall control and direction of the complete development effort. This organization is named HBow (for Bocket Fugine Operations - Iluclear) and includes personnel qualified by experfence in the technical, administrative, and managerial sk112s required for this conglex effort. The Westinghouse Astronuclear Isboratory is the principal 
aubcontractor and 18 reaponolible for developinc the Plight reactor and assoclated muclear aspects of the prograw. This organization is located in Pittsiburgh, Pennsylvania. Aerojet's Liquid Focket Plant at Sacramento, Callfornia, is responsible for developing most of the non-nuclear engine components and subsyateme. Also, AM Atomica, a division of the Anerican lachine and Foundry Company, is responsible for designing, developing, fabricating, and installing the unlque, revotely-controlled oquipuent for asserbling, disasserabling, and transporting the angine during its dovelopwent tests in Nevada. The fourth principel particlpant is the Bendix Corporation which is responsible for developlng sertain radiation-resistant control system components.

When INOW is functioning at Aerojet's Sacrimento Plant, it will be one of three rajor operations headquartered at the Sacramento faclifty; If quid Bocket Operations (IRT), Solid Bocket Operations (SRO), and RBON (Rocket Ingine Operations - Nuclear). Combining and int sgrating the functions previously perforwed by Frow in Azusa with the development operations being conducted in Sacramento should provide for a more centralized and erficient way of fulfiling Aerojet's prime contractor responsibllitles with regard to the HWAVA developwent program. The Bwod Orgenization Chart is designed primarliy to weet the speciflc requirements of Contract SWP-1. It has the approval of both Corporate Management and the Customer. The besic organlzation and lsey personnel are show under "Organization", Section III below. Frow, as an overall operation, is projectized since it is basically a one project orgenization, and 18 likely to remain so for soms time. Within the basic organization, the activities are functionel as indicated on the charts.

As indicated previously, Aerojet-Ceneral Corporation is prime contractor for the IEHVA engline development. Westinghouse Astromuclear Laboratory is the principal subcontractor for the reactor develogment.

Basically, Aerojet's responsibility is outlined as follows:

1. Responsibility for overall program plenning, encine design, program integration and program control.

2. Rasponaibility for reactor-tomengine 1aterface, both wechantcal 1 and functional and for interface control drawings and gauges.

3. Responsibllity for overall engine control system and control sensors or instmmentation as applied to non-nuclear hardware.

4. Responstbility for overall program safaty, both nuclear and industrial. In the latter case, the eudit function is exercised.

5. Roeponsibility for program quality assizrance plan and of overall engine and reactor coxponents and exerclse particularly the audit function on the reactor components. 
6. Responsibility for overall activities at IRns and with particular ermpasis on planning, scheduling, safety and quality assurance. Specifically, Aerojet is responsible for engine testing and the activities on engline test stands and E-MAD (Bncine-braintenance, Asserbly, and DIBassembly Bullaing).

7. Responsibility for review and approval of Westinghouse procurement pacieages.

8. R oponsibility for review and approval of all NRDs test plans and activities.

Customer technical direction is vvested in sirp-Cleveland and is often very detalled. 2b understand Aerojet's role better, it is desirable to review the Westinghouse independent responsiblility as viewed by the Customex.

1. Responsib1lity for reactor mechanical and nuclear dealgn.

2. R sponsiblilty for reactor (Inner loop) control system, sensors and instrumentation.

3. Responsibility for Hestinghouse vendor pexformence and quality assurance.

4. Responsibility for preparation of reactor test plans and speciIlcations.

5. Responsibility for reactor testing at UIRDS within the safety, quality assurance and approval limits as vested in Aerojet.

Within the above broad conotraintz, Aerojet provides the necessary technical, fiscsl, and programetic direction to Westinghouse with the orgenization outlined. Cocmnenication at the workeng level is carried out at the worleing level and 13 encouraged to ensure timely tranemisaion of data. Iechnical data Is trangitted by the Program Manager's office. Official progras direction, technical or otherw1se is transmitted by the subcontracts Ofrice which administers the subcontrect with Hestinghouse. A large subcontract for remote hanlling equipment is also administered by Subcontracts. This contract is with the Atomies Division of Acerican Rachine and Foundry . Company. 


\section{F. SFECIAL ORGAMIZATIOMAL REQUIREMAMTS}

1. The DARVA program has three unusual characteristics

which rake it desirable to operate as closely as possible as an

integrated grouxp. The first of these is the ABC "Restricted Data"

requirement which necessitates all encineering and offlce personnel to be cleared itnal Secret or equivalent based on $Q$ clearances and requires special handlinc and confined areas for docunentation. Recent difflculties with Security offlcers sbould provide ample evidence of these problems.

2. The second unfque characterist1c is the special requirement on hardware resulting from the need to operate rellably in a radiation environment. It is essential that pereonnel be knowledgeable of these problems and capable of designing equipmont to rithstand the combined radiation and more complex environments of temperature, thermal shock, vibration shock, etc. Rotation with or part time assignments to inexperienced people would drastically increase costs, jeopardize schedules, and compromise designs. The following organizational reflections of the above merlt special exphasis:

\section{Projectizing of IHRVA Test factivities}

a. The projectization of the NRRVA test activities 1s essentlal - using the following general ground rules:

(1) The managenent of facllitles, including test stands and leboratories, where InSRVA is the majority user, be immediately assigned to KEON. Personnel assoclated with these facilities be transferred to REOR.

(2) Management of design, supervision of conotruct1on, modification and activation of facilities and equipment for IHAVA use be assigned to RrON. All personnel assoclated with this effort be transferred to REOH.

(3) In all areas where NERVA testing is accomplished, REON be assigned managersent responsibilities for safety.

\section{Test Stands}

That Test Siands C-6, H-4, H-4A, H-5 and H-6, where INERA is a majority user, should be assigned to kifON for nanagewent control. Teat persomel, both salary and hourly, should be transferred to the REON Test Services Department. To provide a more cohesive operating group, propellant logistics and loading required for the "H" area should report to this REON Department. Area safety, includine the Cryogenic Iab, should be assigned to REON to qualify under ABC regulations and to provide a complete project service. 
5. Instrumentation Callbration and Valve laintenance Center

The existing Instrumentation Calibration and Valve

Maintenance Area in Test Zone " $H$ " should be under the cognizence of the NERVA Procram. I e Interchange between this $1 \mathrm{ab}$ and the Data Reduction Center will be significant. The lab ahould include transducer calfbration and Instrumentation service capabilities, as the present IRP Lab provides only a linited facility for WMO use.

\section{Cryogentc Laboratory}

The Cryogenic Iaboratory was originally scheduled for majority IIERVA use. The IIWRVA requirement for such a laboratory was the basic Justification used in obtaining Government funds for its construction. IERVA is now the majority user, consequently, the management of this laboratory should be assigned to Riron. Personnel, salory and hourly, should be transferred to the KREOR Iaboratorles Department.

7. Instrumentation and Control Personnel

The present Instrmentation and Controlo Iab at Sacramento is used approximately 25\% by IIRRVA and the Transducer Iab ut1lization by IIFRVA is 15\%. In these two instances, we belleve the personnel who are involved in NERVA work should be asgigned to the BEON Laboratories Department.

\section{IDFRVA Facilities}

The creation and activation of the NerRA facilities at Sacranento have been seriously delayed because of the difficult interface between profect designers, facllities desicners, construction contractors, test services and our customer. It will be advantageous to combine personnel concerned with NसIVA facilities requirements throughout the program, both at Sacramento and 1 Iro, into a sincle project organization. This type of organization w11l help to produce a consistent NERVA Test Procran. It is recorasended that all management control and associated personnel concerned with Tasks 5 and 6 be transferred to the REON Facilities and STE Department.

9. Mufacturini Control

IFERVA, at this tive, is hardware "poor" and lone lead times are a continuing problem; we have test stands belnc activated and comitwents made for "off-site" radiation tests on components, as well as comitwonts to the MrX reactor development program that must be met if we are to enjoy good customer relations. To this end it is necessary to extend the projectization of the IIFENA progran into the lenufacturing Control area; accurate, precise, and detalled data must be avallable in this operetion to alloi continuing assessuent and reporting to RFON Management and to the custower on this critical operation.

The evaluation of the data will allow REON lianagement to exerclse Its judpont on the nertits of becing hardware or backup or altern te source and inake otiner critical decisions concerning scheduling, assembly testing snd tooling. 


\section{IEERVA Assembly Iepartment}

This department will be responsible for assembly operations and will exercise direct supervision of all personnel. It will maintain a bonded area for spare parts and assembly storage. Hardware stores and tool crib functions are additional responsibilities. The IIFRVA assembly area vill include ITA and valve assembly; CFDIS, MRX, and engine asscubly; nozzle test assembly; support equipment assernbly; radiation effects test pallet assembly; and a hot shop area formaloactive parts.

It is anticipated that perts from outside production or fram the Sacrassonto manufacturing shops will flow into the assembly area for final assembly, acceptance test, and shipment.

The "Hot Shop" is a necessary and pecuiliar MHAVA requirewent. Its punction is to provide facilities as necessary to repair and modify contaminated engine parts and to prepare activated samples for material analys1s.

\section{Product Assurance}

The quality and reliability of the MRRVA engine is of prime ingortance. The difficulty and complexity of the development job and the history of technical difficulties to date does not permit a margin of deviation from specifications which micht even remotely result in a test fallure which could jeopardize the entire program. The customer bas reflected the importance placed on quality and reliability by insistinc on assignment of clearly established responsibility for establishing the Product Assurance Plan, for auditing periormence and for initiating corrective action in case of non-cciformance to a staff whose sole function these are. Because of these considerawions, the degree to which it is feasible to ut1lize personnel not under $a$ rect IEON control for certain aspects of the product assurance function and the vays in which they are utilized must be determined by the FREN project asaurance menacer in coordination with the Sacramento Woriss lianager.

As in the safety area the degree of opecialized knowledge and ablitity required of the REON product assurance staff to understand and cope with the problems arising out of the development program precludes wore then an adrinistrative cognizance by personnel of the Sacramento plant ataff.

\section{SaPety}

Because the NGRVA progran hes at its heart a nuclear reactor which produces phenowene which are hazardous in the extrewe and which are best understood by nuclear specialists; with respect to safety, it is strictly Goveraed by Atolic Inexicy Consission regulations and requirements. These replect the unique corplex and interactive conditions involved in a nuclear environment as rell as the hichly spectalized technical problems of 
radiation, use, assembly and disassembly and storage of radioactive equipment riaterials and wastes. The program also poses problems concerning other exotic and hazardous materials and physical extremes of temperature and working conditions which zequire continuous and speciallzed lonowledge and experience. To neet the close, detailed supervision of the custorser and the $A E C$ and to give the aafety aepects of the program the attention they deserve and to reflect the extrese sensitivity of safety in the eyes of the public, a lluclear Safety Division has been made a major conponent of the REDN orcanization.

This organfzation must be able to discharge its responsibilities in accordance with AEC requirements and its professionill lonowledge and experience. It cannot discharge this responsibility if through organizational standard practice, it is subordinated to organizations with werely industrial safety competence.

\section{Subcontracts Adminiatration}

The particular substantial abcontract activity includinc the managernent of the Weatinghouse subcontract which represents nearly $50 \%$ of the NEHVA program expenditures, requires direct and continuous contact with the other members or the REON tear. The relationship of subcontracts to the overall effort, the sensitivity of our subcontracts, the special knowledge required, relationships with our custorer and our technicel staff, all demand that they be administered under common direction and that this effort continue in Its present pactord. Therefore, FWON will maintain the administration of 1 to principal subcontracts and consultants under its direct jurisdiction. In addition, these are certein, out of the usual, aspects of procurement and raterial which alvilar considerations dictate be handled by IFEN subcontracts personnel. These will be worked out after the nove.

\section{REOS Technical Information Center}

This facility is an important means of providing stateof-the-art inforciation to the technical staif of cultivating and exploiting sources of information, of facilitatinc flow of information within the staff, of providine rapid response to requiremente for information and of assuring that security requirements are met concerning accountability, storase, marleines, reproduction, destruction and need-to-loow for the thousands of clasalfied documents which the progran utilizes and generates. It will integrate a central project file operation with the outside specialized documents and other publications applicable to MERVA.

Tatis facility is an integral part of performance of our tecinical job and must be perforised by personnel knowledgeable as to our subject matter and directly responsive to NERVA Progrern needs and priorities. 


\section{Data Control.}

The IVERA security requirements, while no more severe in theory than any other classified project, are in practice unusually severe because of the high frequency of Restricted Data documents and drawings. REON is required by contract not only to generate drawings, but also to file and index drarings of all subcentractors, plus a large reference Pile of drawlings of tine Ios Alamos Scientifle Iaboratory, many of which are Confidential Restricted-Data, - which require careful handling because of security clearance and need-to-lnow considerations. This large volume of $\mathrm{C}-\mathrm{RD}$ must be protected by reatricting the area in which the natertal is generated, processed and stored and access granted to personnel of othex organization.

Integration of drefting and date cortrol functions is desirable because they are so closely related ir operation. Drawings are nicrofilmed on cormpletion or receipt frow aubcortractors, a Recordak viewer (AGC owned) is available for quick reference, and a rented Zerox printer furntshes stendard size prints for more extended use. This integrated function has provided excellent and rapid service to the project for about one year, and its continuance will. facilitate the handling, storage and reproduction of drawings. A blueprint nachine has been requisitioned to permit check prints to be made available irmediately, to permit rapid distribution of prints of incoming velluxus so that there can be mexinum speed in responding to program requirenents, and for officetype reproduction of materials too large for office copiers.

The complexity and security classiflcation of the engineering data utilized by and produced by this program and the rapid service needed and the importance of this function are reflected in the direct contractual support for this activity. Its operation as an integral part of REON is essential.

\section{Beproduction Area}

The process of preparation of millions of peges of techical and administration material requires both quicli response, immodiately avaliable facility and the publications caparlitities associated with "Irechical Publicationg". Preparation of Raor materials is frequently a relterative "; "ir process of review and coortination which requires running of several alto versions prior to publications. In addition, virtualiy all correspondence and manargement publications are duplicated on ditto for provision of information to those concerned. IHght controls are meintained to avold Inproper duplication of classifled information. This service is in full operation at least 9 hours per day. 
II. MANFCWER

TEOAi will have 670 poople at Sacramento. This number 1ncludes manacement, englneering and related personnel as sumarised in rable I. Further, 101 addi.

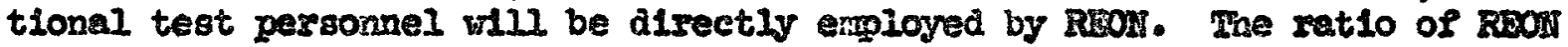
direct to Indirect personnel at Von Karnan Center and IRBS Irow Dece.3ber 1902 through March 1964 can be determined from Flcure 10. The 670 wanporer estimate 1s ussed on a ratio of $35 \%$.

Approxdmately 250 people have made afflrmative comnittinents to inove from Azuse to Sacramento. An additionol 10 have not as yet mode decisions and a further 84 occury positions which will not be moved to secramento until september or later. To date 187 employees are now in Departinent 8200 which is verving as a holding department for Rwoll personnel at Sacramento. A minimum of 208 positions reasin to be Pliled during the move period. These pogltions breais down as follows: Five executives and manarers (selory), gh professional and technical (salasy), 24 adminlstrative (salary), 15 technical (hourly), and 70 clerical (hourly).

Although there are no comnittients to move hour ly clerical personnel, approximately 20 cleared, sililled and experienced peogle in this category have expressed a desire to follow their jobs to secranento at their own expense.

A major problem in the tinely fliling of vacancles will be the requirenent of final military security clearences or interim cleasences based on $Q$ clearances, before access can be cranted to "Restricted Date" under the Atonic Bnercy Actiof 1954. Experience at Von Karman Center and reported Sacramento experience Indicate that completion of new clearences requires more than three conths. Reaffirmetion of clearance upon chance of exployers taies fron 10 days to 3 abnths. The cleevance requirement ralies it virtually inposalble to utilize pereons with 1 ess than final military clearances at wore than a small fraction of the capablilt1es. The larger the number of uncleared persons, the more difficult it 18 to utilize them because the available unclassiffed vorli or worli of lower clessiflestion can be spread only so far.

With the 1083 of 138 of the technlcel and management pereonnel and 70 of the clexical personnel, frow vill heve a problen of meintaining contimulty with respect to program baclivround, relationships, and the mechenics of getting things done. It is therefore essential that experlenced personnel of all types be retalned on the program even at the expense of some other considerrations. Amonc other actions, REO vill, therefore, transfer to Sscramento such bourly enployees whom we feel merelt retention and whose trangfer w11 be conduclve to continulty and productive effort; ouch transfers to be at the expense of the employee.

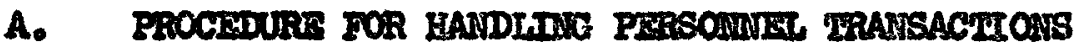

To control effectively the handilne of all personnel transections pertaining to the move of Rlwow Operretions to sacramento and Ias Vegas, a central control point has been esteblished in the Administrative Bervices Division in the offlce of W. G. Clayton. All trensections wlll be coordineted with the 
Suiramento and Von Kaman Center Industrial Relations Divisions in order to provide (1) maximum ut1lization of all avallable Acrojet personnel, (2) continutty of operation, and (3) overall program econouy. The followinc procedure has been established and will be followed insofar as practicable.

1. When the number of direct-charge personnel has been estabIshed for each departinent, as required by PD-1005, and the authorized number of indirect personnel has been added, a cormlete depertmental positionucontrol chart w1ll be prepared on which each position will carry a control muber. As soon as these departmental manpower cellines are eatabliahed, a formal offer memo (see Flowre 11) will be submitted to each invitied employee.

2. After the offer memos have been signed and returned, 2 11at of all "unassigned" personnel will be prepared and distributed, shovins the "earliest release date" and the "latest release dato" for each eiployee. the latter belng the employee's layof date. These dates will be established by the cocolizant department managers.

3. For each vacancy that eypears on the position control chart, an eiployee requisition will be prepered by $W . G$. Clayton at the request of the department manager. The requisition w111'Indicate the proper joi class1fleation and detalled description of the duties and qualifications of the candidate. Approvals of enployee requialtions at Azuss will consist of the Divioion llanager and G. I. Eyland or R. H. Hardin. For all Sacramento openings, a copy of this requisition w111 be forwarded to Mr. George Harris, Department 8200 at Sacramento, for proper processing throuch the Sacramento Industrial Relations DLvtBion. Sectemento Industrial Reletions will indicate within a weel: whether or not they have ouftalle candidates for each requisition. If they do not, candidates at Azuse will be interviewed for the job.

4. If ouitable candidates are avalioble at secramento, sacramento Indugtrlal Relations o1ll notify Ceorce Barpls of Department 8200 and be vill coordinate the palling of resumes and the arrancements for interviews. If a Sacramento candidate 18 acceptable, the Departnent Manager will so advise Ceorge Herrys. The Iosing department will initiate the Chenge of Status and the employee will be transferred Into Department 8200 and J. J. Peterson will sign as the recelving departnent head.

5. If a ouitable candidate is not evailable at either sacram mento or Azusa; then Sacramento Industrial Relations will talie eppropelate recruiting action to IIIl the vacancy, especially in the areas where nuclear exsperience 18 mandatory.

6. Froloyee regulaltions for openings within the Who Division will be processed flrst throuch the Von Karmen Center Industrial Relations

Division and then (if no outtable candidates are avaliable from Prowotion and Transfer 1ists) through the Sacramento Industrial Relations Division for appropariate recrultments.

7. No employee requigitions w1ll be required on 1 June 1964 to trensfer any euployee from Department 8200 or from RFon-Azuse into the 7000 
serles of departwents. These vill be handled by . G. Clayton on a "mastransfer" basis. All employee requisitions still open at that time will be changed to reflect the appropriate 7000 series department number.

8. After the manpower ceilings have been established for each department, and the position-conirrol. chart bis been epproved by the cognizant Division Nangers, the sigmature of G. I. Ryland or R. H. Hexdin will suffice for approval, after Division Mamager signature, of all enployee requisitions and all REON personnel traneactions which do not require selary comittee action or approval, and that are compatible with current cellings and rerit increase budget Iimitations. 
ST.

\section{ORMAIIIATOYS}

\section{A. Gigm:}

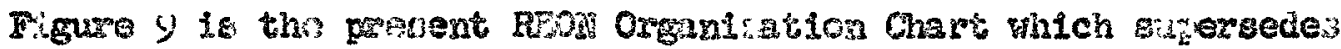

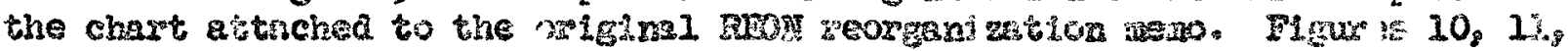

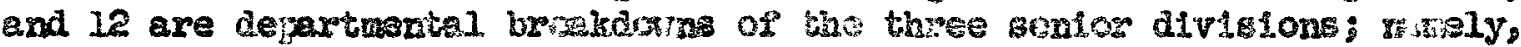

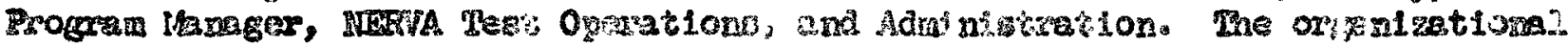
level of each bos: 18 furni thed in Seetion $D$.

\section{B. FITHCIPAL FUNCBONO}

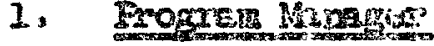

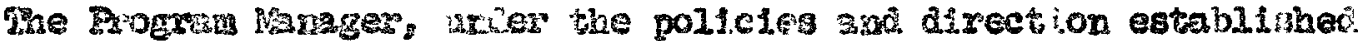
by the Progren Dixector and within the guldelin whituly agreed unon with

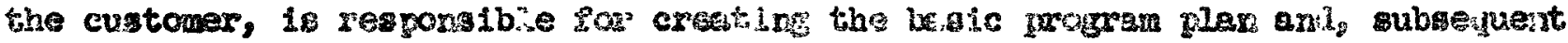

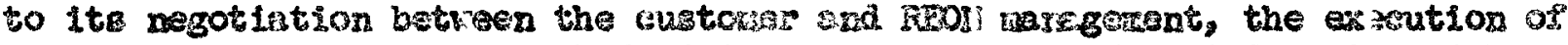

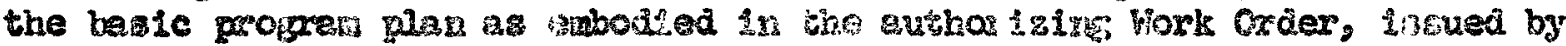
RroD Contract Adurini tration.

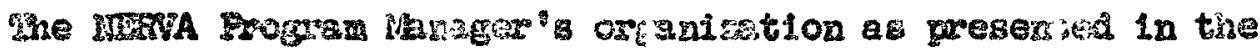
organizational forme elewhere, utillzes the tr leats of those personuel

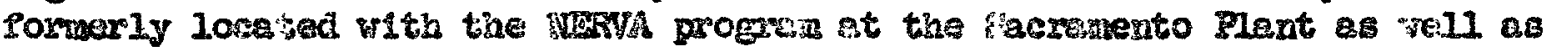

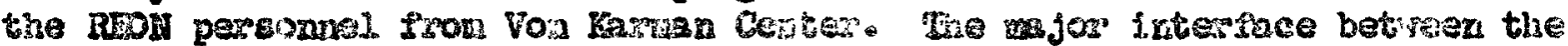

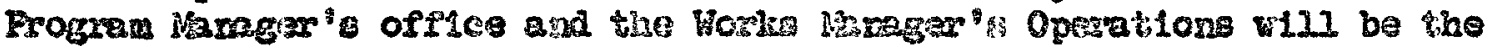

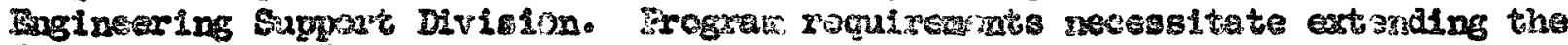

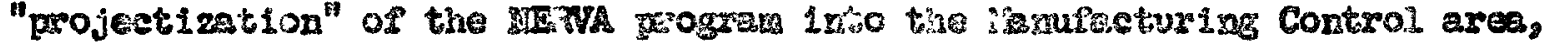

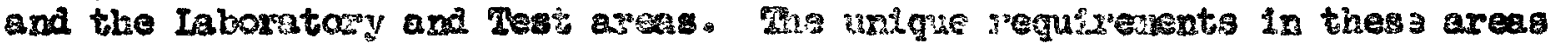
dictate the neessity of HION Juxisdiction crex shose portor where control is eseential to customer atighetiox.

\section{Mater Safety Divis}

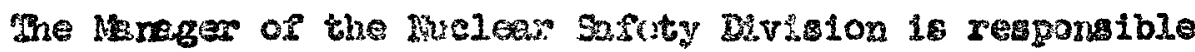

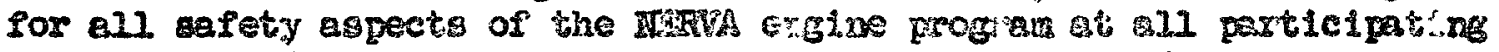

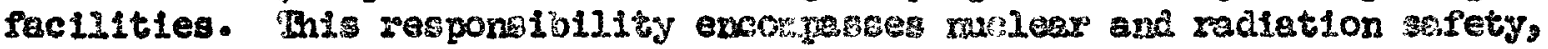

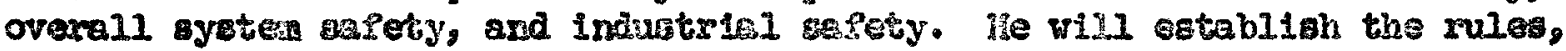

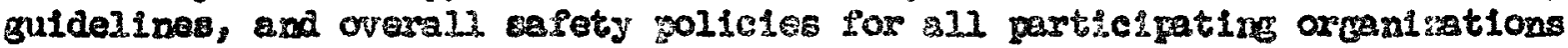

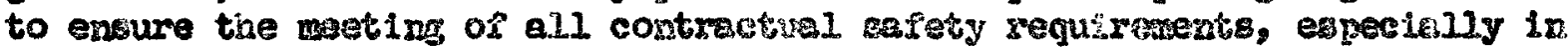
the aree of hazards unique to a melear developuent progran includist radiation, and the storaze, handiling and disposel of rodicsetive terelels. He has the responsibility for the survellinnce and auditins of asety sctivitien at esch plant and fecllity and for initiating remedial tetion when erowiles are discloged. His offlce will be the interface between BWON and the wosks Namager's office in a.11 ratter"s pertaining to arsaty.

\section{MLFVA Pegt Oparations:}

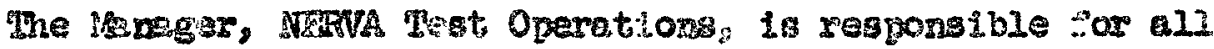

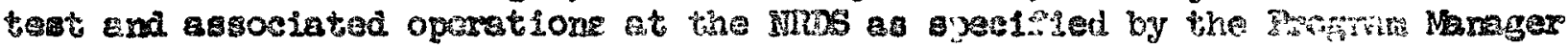


and for Safety and Qullty Assurenee within the policies eatablishod by those respective activitles and as apmoved by the Program Directos. He has responsibility for conduct of all test operations pertaining to IMPX (R-MAD and Teat Cell " ${ }_{A}^{13}$ ), FIS-1, and EaMA, inciuding facilities, equipnent, plans, instruantetion and control, and data reporting. His ofilce will provide the interface between IUFWA Mest Operations and the other divialons of REON.

\section{Product Assurence Division}

The Manager of Product Assurance is responsible for the establishment of a Product Asqurance Plan for the IIIIVA program which mets all contractual requiresents as establiahed and approved by the custower. He hes reaponelbility for approving the Froduct Assurance Progman Rlans for all particlpants, for auditing the performance of ch plant againgt approved ctandards, and for initiating correctiva action where needed. He is responsible fox the intenpretation of custcmer requiremants and for obtaining cuetomer approval of Product Aseurance ectivities. Major participants include the Bacranento Plant, Von Karwan Center, ITEFA Pest Operations at NRDB, Westinghoune Astronuelear Iaboratory, Vestinghouse Astrofuel Faclilty, and Arenican Prachine and Fourdiry.

\section{Adminietration Division}

The Mragar, Adralulitration, is responflbie for Cortracts, Subcontrects, Intermal Program Adminiatration, and Procram Amelysis. His offlce has the prive responsibility of the Interiaces between Rison and the customar, the wajor subcontractore, and the various service divisions of the secremento plant. His responsibilitles under Program Analys is include independent eveluation of the overall performence of REON and our progreas tomard custower astablished milestones. These responsibilities include overall Ilscal control and consolidated technical and riscal progress reparting. H1s function under Administrative Services will include the optimum ut111zation of sacramento service aroups in the interest of, and consistent with contimulty of operation and overail progran efficlency and economy, especially in the ares of timis and effective staffing of the Rmor organization.

\section{Staff Ase igments}

In addition to these Iive jor divisions, the REON organtzation will aintain a smil stafe of highly qualified engineers or selentiots for the purpose of handiling special problews, investigations, and to act as assistants to the progmam for non-atandard Rnon activities. The Advanced Concepta DLvision will carry out the IRlaD programs of REON, conduct non-

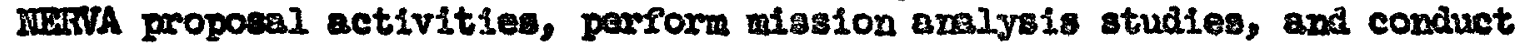
customen relation activitien with potential users of mulear rocket engines. 


\section{c. TAST ORCAMIZATIOA}

1. The WHEA Relerse Elon, as shom in PD-1004, indicstas by work order release nurber, the coguizerst, (responsible) departuenta for all elements of woris to be conducted in contract Yeas 1954.

2. Por Bumay purgoses mucis as cuetomer technical contacts, budget allocations, roport and or cost btudy ingus review, etc., the following individuele are absigned cognizance of the vartove gubtask of the contract:

Subrask lluwber

1.1 (1ess 1.1.8)

1.1 .8

1.2

1.3

1.4

1.5

1.8

1.9

2.1

2.2

2.3

2.4

2.5

2.6

2.7

2.8

2.9

3.0

3.1

3.2

3.3

3.5

3.6

3.8

4.1

4.2

4.3
Cognleant Act1v1ty Manoges

P. W. Rowe

P. H. Rowre

I. L. Odgers

P. 1. Rowe

I. Is. Oagers

I. I. Odgers

B. Mandell

I. I. Odgers

D. Holzman

D. Holzman

D Holzaran

I. L. Odgers

J. B. Philipson

D. I. Dewing

J. B. Pnilipson

N. E. Frrickson

H. D. St1nnett

D. Bolman

P. H. Rowe

N. I. Errickson

ฟ. E. Exickson

N. E. Erricleson

I. E. Erickson

II. E. Errickson

J. S. Robbine

I. R. Shirley

R. B. Mastercon
Subtask Manager

R. V. Evletb

C. K. Soppret

H. B. Bozmemen

C. K. Soppet

J. J. Beereboom

J. I. Irvine

B. Mandell

J. B. Williams

M. J. Meder

M. J. Neder

M. J. Neder

T. F. MeGrath

C. F. Teyse

G. Birdsell

D. S. Duncan

A. Wilson

C. $\mathrm{BA}$. Pidee

J. I. Carton

T. M. Pruaden

W. J. Kurtz

D. I. Is imbacher

I. F. White

W. J. Kurtz

I. E. White

J. J. Sogorlie

J. H. DHederich

P. D. Kahn 


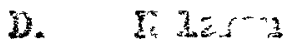

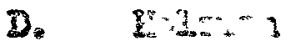

D. Enerer

M. I.. Fis

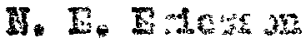

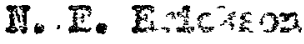

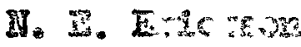

I. I. W stera
D. $\mathrm{Drgfres}$

J. .s. Carton

I. It Carton

N. i.. Erickron

Ii: I: Exiciesson

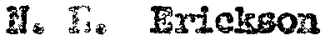

W. 8 . $\mathrm{xux}$

I. Is Haite

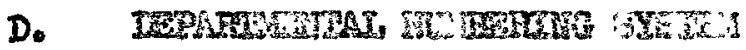

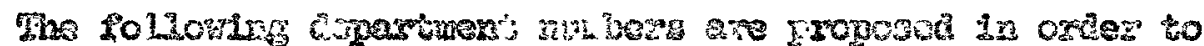

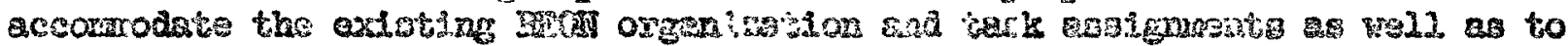

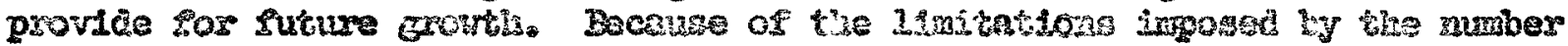

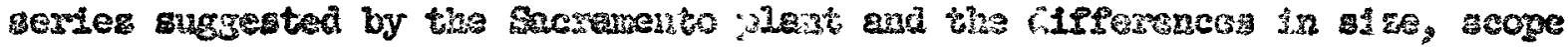

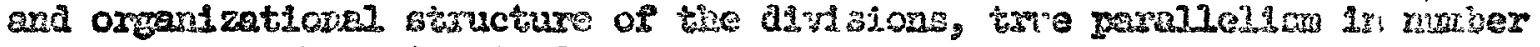
crougs connot. be maintained.

TSIRARIMEAT 170. * *

7000

7000

7040

7100

7120

7121

7124

7127

7130

7200

7205

7210

7220

7230

7231

7235

7240

7260

7300

7310

7320

7330

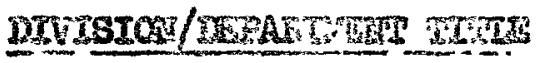

Fecar

Fochical Etage

Advancea Concupts

Acuinistrotion

Brogram Anely 3ds

Documentation Services

Procaran Ivvaluntion

Fiscal Control

Contracts

IDEFA Togt Oparations

Qunlity Control

Acruinistration

Ieoltia \& Soxety

MVX Operations

IV-FAD Cocxatiuns

Test CoIl "A" Ops.

ExS-1 Gorations

E-IfAD Oparetions

llaclear Rapety

System Safety Arriysia

Inclear is Radiation sarety

Industrial So:3ety

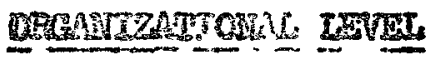

Oparations

Grexptions Start

Operations Staff

Sonior Diviaion

Divisios

Doparturent

Departwe nt

Departuseat

Divibion

Sonior Divialon

Departisent

Departuent

Dogartacut

Division.

Departinent

Departiucnt

Division

Division

Divieion

Departinent

Dopartinent

Dopartwent

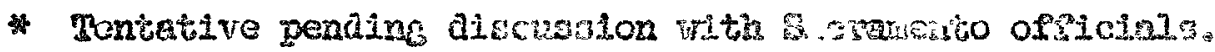

Section III, Page 4 
7400

7420

7440

7500

7510

7520

7530

7540

7550

7560

7561

7564

7610

7620

7621

7630

7631

7632

7640

7641

7646

7650

7660

7670

7672

7676

7680

7681

7682

7690

7691

7656

TT1O

T720

TT21

$T 726$

7730

7740

7741

7746

7750

$\pi 760$

TT70

$77 T 1$

TTT4

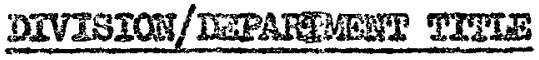

Product Assurance

Audit \& Surveillance

Product Assurance - Sacto

Program Manager

Stare Bagineering

Thermodynamica

Materioja

Stzuctures

Iluclear Analysi:

Program Controls

pierer

Budget

Component Davelogment:

Propellant Feed System

Trurbonverp Assembly

Tharuot Chamber Aseemibly

Nozzles

Pressure Veasel Assy.

Instrumentation 3 Controls

Instrumentation

Control Syatexn Desion

Fadiation Bfect:

Project Ingineering

Integration - NNXX

Inclear Subsystem Intogration

IIXX Projects

IITRVA Exheust System

Hot Cas Supply Sys tem

IWIS Duct System

IUERIA Ingine System

Experimental Ingine

CrDins

Ingineering Support

Iaboratory \& Teat Operations

Test Planning

Test Services

Pacllity \& STS

Manufecturing Contion

Planning, Control \& Liaison

Assembly Bhop

U13RVA Sugport Syetema

Englneering Services

Systems Anslysi:

Performance Analysis

Data Analysis

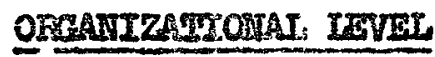

Diviaion

Sentor Department

Senior Depertment

Sentor Division

Divia1on

Senior Dopertment

Sentor Department

Senior Department

Sentor Department

Division

Depaxtarent

Departuent

Division

SenIor Depertrnent

Department

Sentor Departmeat

Departanent

Department

Sentor Dopertuent

Department

Department

Sentor Departuent

Divirion

Senfor Department

Department

Department

Sentor Depertment

Department

Deppartment

Benior Dxpartment

Department

Depertument

Divigion

Senior Departwent

Departwent

Depaxtment

Sentor Depertment

Senior Department

Department

Departwent

Sentor Department

Departinent

Division

Department

Department

* Tentative pending discuasion with Sacramento ofricials. 
IV. FACITIHIES

A. GHIRAL

The prine-contractor role of REON, coupled with unique securlty requirements necessitate careful consideration in regard to facilities. The move to Sacramento and the resultant integration of operations creates the following as facllity requirewents:

1h. Creation of a basic FFod work area suiteble for the management, design and deslen Integration of the engine development under the SIIP-1 Contract.

2. Creation of speclalized fecllitles which will contribute to analysis, design, fabrication and test efforts.

These generalized requirements are described in more detall in the following peragraphn, and an estimate of capital expenditure is furnished in Table III.

\section{B. OFHICE SPACE}

At Von Karmen Center froul bas approximately 42,000 square feet Inclusive of a utility core and major corridors and the area has been occupled by a maximum of 470 people. This occupancy level has been too crowded to permit effective working conditions, good housekeeping, a vusinessIike appearance, and compliance with reasonable safoty requirements. WithIn the area are 8 band and 50 easy vall offices occupylng 7393 square feet.

The Frow organization (exclusive of the Vice President and the Assoclate D(rector) requires 7 offices for the senior managers who report directly to the Vice President. 13 additional offices are required for menagers of mejor functional segments. Also, there are office requirements for a Westinghouse representative, and an SMPO representative and h1s staff. In addition to the above, offlces whlch provide opportunity to conduct business and work in relative privacy and quiet ars needed for 45 additioanl personnel. These latter aployees carry on lroportant discussions and negotiations with the custaner, oubcontractors, and assoclats contractor peroonnel, as well as superviaing substantial organizations. In stetus and tenure they are Benior Aerojet and Fecis personnel.

Projected strencth at Sacranento is approxinately 670. Of these, approxinately 33 equire individual "banker;s type" offices in addition to those Indicated above. An additional 33 senfor pexsonnel should be housed, no more than 2 wen to $12 \times 12$ cubicle. There will be 3.20 secretarial personnel of whon $110 \mathrm{inll}$ be houssd in the specialized areas outlined below. The aggregate requirenents for the obove, in aquare foet, is 45,224 . General desk space is therefore roquired for 334 perrons. A reasoneble anount of such apace pse person is 75 gquare feet excluatve of aisles and corridors, etc., which bxings the net requirement to $67, \varepsilon 74$ (refer to Irbile III). 
A perimeter security wall is requiled to create a companycontrolled sccess aree. Such an area permits proper eafeguarding of the large amount of material classifled Confldential-Restricted Data. and higher in FEON possession. In the absence of such sefeguards there would be a continuing hazard that persons not holding final govermentBranted security clearances would have access to Restricted Data. Such an area simllar to that which REON currently bas at Von Karman Center, also contributes to Increased work output by reducing the need for openIng and closing file cabinets during the day. At the entrances to such an area securlty cates would be manned by FEON receptlonists. The ares for uncleared personnel must be outside the controlled access area, as shoulds a lobby, areas for unclassified discusafons with vendors, an area for conduct of interviews of uncleared job candidates referred by Industrial felations, and areas for displays of model.s and wockups and visitor coondination.

The following pages the names and titles of the personnel who will occupy Hat offices in the following respective categorles; sentor manegement personnel, diviaion management personnel, senfor departmeatal management personnel and departmental management personnel. 
J. J. Peterson

W. C. Beckwith

G. I. Fyland

J. B. Phillipson

D. L. Dewing

W. D. Stinnett

C. M. Rice
Tech. Staff

Advanced Concepts

Mgr. Administration Sr. Div.

Ner. Nuc. Safety Div.

Mer. Product Assurance Div.

Progrem lanager Sr. Div.

Associate Pro. Mer. Sr. DIv.
7000

7040

7100

7300

7400

7500

7500 
I. Borrastein

R. H. Hardin

J. J. S. Daniel

E. Phara

V. Millex

N. Drickson

J. H. Beveridge

J. S. Robbins

I. L. Odgers

P. W. Rowe

D. Holzman

B. Mandell

H. A. Flaia

WAWL (Weller)
Technical Staf?

Mgr. Admin. Services

Mgr. Prograin Apalyris

Mgr. Contracta

Mgr. Subcontracts

Mgr. MIO

Mgr. Staff Engineering

Mgr. Progran Controls

Mgr. Component DIv.

Mgr. Project Engineering

Mgr. Engineering Support

Mgr. Systems Analyeis
Ops Stafe 7000

Div. 7110

IIV. 7120

Div. 7130

Div. 7160

Div. 7200

Div. 7510

Div. 7560

Div. 7610

Div. 7660

Div. $T 710$

Div. T770 
D. L. Duncan

C. F. Leyse

A. Haeseman

G. Birdsell

C. W. Bunik

G. Kaveny

J. Vreeland

H. H. Bornewan

J. J. Beereboom

N. Irvine

J. B. W111ams

C. K. Soppet

T. M. Prudden

R. Evietb

R. M. Beattie

J. I. Carton

M. Neder

T. Walon
Mgr. Syatems SaPety Analyais

Mgr. Muclear Radiation \& Safety

Mgr. Industrial Sasety

Mgr. Audit \& Survelilance

Mgr. Product Assurance - Sacto

Mgr. Thermodyamics

Mgr. Materials

Mgr. Structures

Mgr. Nuclear Analysis

Ner. Propellant Feed

ligr. Thrust Chamber Assy

Mgr. Instrumentation \& Control

Mgx. Falation Effects

Mar. Integration NRX

Mgr. NGRA Exhaust System

Mgr. LFriva Engine System

Mgx. Laboratory \& Test Oper'ns.

Mgr. Facllity \& SWE

Mgr. Manufacturing Control

Mgr. IMEVA Support System

Ass't.Mgr. J J SunA Suport Syrtem
Sr. Dept. 7310

Sr. Dept. 7320

Sr. Dept. 7330

Sr. Dept. 7420

Sr. Dept. 7440

Sr. Dept. 1520

Sr. Dept. 7530

Sr. Dept. 7540

Sr. Dept. 7550

Sr. Dept. 7620

Sr. Dept. 7630

Sx. Dept. 7640

Sr. Dept. 7650

8x. Dept. 7670

8x. Dept. 7680

Sr. Dept. 7690

Sr. Dept. T720

8x. Dept. T730

Sr. Dept. T740

Sr. Dept. 7750

Sr. Dept. T750 
H. Johnson

D. Vantica

B. Houghton

Visitor Control

Six Sr. Fingineers

Bob Swanson

J. Carroll

W. G. Clayton

R. Masterson

G. N. Elsenbart

I. Shirley

J. I. Dooling

R. C. Bawbell

S. F. Collins

R. T. Biko

J. J. Sogorka

V. J. MeDevitt

J. Beattie
Advanced Concepts

Advanced Concepts

Advanced Concepts

Advanced Concepts

Open Regs

Consultant to Sr. Dept. 7690 Evleth

Staff to B. Mandell

Mgr. Mampower \& Offlce

Mgr. Information \& Security

Mgr. Documentation

Mgr. Program Evaluation

Mgr. Fiscel Control

Mgr. (Within Contracts Div.)

Mgr. (Within Contracts Iiv.)

(Mgr.within Subcontracts Div.)

(Mgr. within Subcontracts Div.)

(MBr. Within Subcontrecte DIV.)

Mgr. Inopection Control

Mgr. Data \& Reports

Mgr. Product Assurance Engr.

Mgr. Audit \& Survelllance

(Mgr. wthin Structures)

(Mgr. within Structures)

(Mgr. within Iuclear Analyris)

(Mgr. Within Nuclear Analysis)

(M8x. within Nuclear Anvlyo10)

Mgr. Program Planning

(Mgr. ParT)

Mgx. Budget

(Mgr. Turbopump Assembly)

(Mgx. Nozzlen)

(Mgr. Pressure Vessel \& Assy.

(Mgr. Instrumentation)

(Ngr. Controls Syrtem Desien)

(Yor. Wthin Instr. C Controls)

(Mor. Huclear Subsyetems)

(Mera. IRX Projects)

Mer. Hot Cas Supply Systu

Mgr. IDS Duct Syotem

Mer. Analysis \& Integration

(Hgr. CTDIS)

Mgr. Iab. \& Test Operations

(Mgr. vithin Fac1lity \& STE)

(Mgr. within Facility \& SYIE)

(Ifigr. within Facility \& STES)

(Migr. within Facility \& STE)

(Mer. Mnufacturing Control
Op Stare 7040

Op stafe 7040

Op Stare TO40

Op Starf 7040

Op stafe 7040

Dept. 7210

Dept. 7110

Dept. 7121

Dept. 7124

Dept. 7127

Dept. 7130

Dept. 7130

Dept. 7160

Dept. 7160

Dept. 7160

Dept. 7430

Dept. 7400

Dept. 7400

Dept. 7440

(Dept. 7540)

(Dept. 7540)

(Dept. 7550)

(Dept. 7550)

(Dept. T550)

Dept. 7560

Dept. 7561

Dept. 7564

Dept. T621

Dopt. 7631

Dept. 7632

Dept. 7641

Dept. 7646

Dept. 7640

Dopt. T671

Degt. 7676

Dept. 7681

Dept. 7682

(Dept. 7680)

Dept. 7696

Dept. TT20

(Dept. T730)

(Dept. T730)

(Dept. T730)

(Dept. T730)

Dopt. 7740 
(Mi. Planning, Control L Leison)

(Mgr. Assembly Shop)

(Bigr. within IJARA Support Sycten)

Dept. 7741

(Mer. within INARVA Support Syatem)

Dept. 7746

(Mgr. Drafting \& Checking - Sanchez)

Dept. 7751

Dept. $T 752$

(Mgr. Central Data Control - Penring)

Dept. T761

Cordon

(Migr. Pexformance Anelysis-Nandel1 Acting)

Mar. Data Analyris

Dept. 7780

Dept. 7790 


\section{c. SERCIAL ROONS}

Special rooms consist of Documentation, Drafting, Central Data Control, Uncleared Area, Iran Roon, Technseal Information Ceater, Conference Room (3), Lobbles and Access Cates (2), Mall-Stationery Supply and Office Copying Center, Cxygto-TWX Fcom, Hanagenent Control Center, Suro Custaner Office, and Generel Storage Rom. 
1. Nlame of Fectlity:

Documentation Ares

2. Nature of Daclitty:

srea must have floor-to-ceiling wallo, 3-tumbler comblnation lock and card. key door, security "Closed Area". One hard offlce required In area.

3. Required Space (Sq. Ft.):

1,600 sq. It.

4. Drawlags, Etc.:

See Apyendix A.

5. Cost of Acquisition (Approx.):

$\$ 6,500$

6. Number of Eersonnel Assimed:

Ten to trelve employees

7. Cognizant Department:

Documentation Services, R. B. Masterson

8. Purpose:

See Item 9.

9. Contrectual Reguirement or Bollcy Development:

Experience has groved the need, over a three-year yerlod, of a documentation service group between the generation of report material by enginoering or other project personnel and the Technical Publications final operations. This service Group expeiltes the submission of report materlal, collaborates with the authors as needed, edits the drefts, essembles illustrative material, and mintains schedules of anticipated work 10od. This latter function, work lood forecast, is correlated with Technical. Publications so that personnel of the latter w1li be available as reguired. This group also assists in preparation of presenta. tion materiel - both by ccatribution to the end yroduct and by handing and expediting of such material through Technical Publicstions and Illustrations groups.

The "Closed Area" requirenents originated in the fact that so many classified activities vould be $1 \mathrm{a}$ process at one time that it was highly impractical to put everything away at the end of one day and have to spread it all out ogain the next day in order to resune work on 1t. The "Closed Area" also strengthens the cecurity position of the cocunentation activity because such activity is centered in one protected aree and access is limtted to cognizant personnel only. 
Such an aree is also Invaluable for the personnel working overtime preparIng materlal for publication. By securing the door to the room, the need for securing material in cabinats each time a trip has to be made to Technical PubIlcations, the Fhoto Lab, or elsewhere is obviated.

Thls area also permits organized open-shelf storage of photo-litho negatives whlah are frequently needed in numerous reports. Such reuse avolds dupIlcation of costs. Cabinet storage for this material is awkward because of carying sizes and shapes of material.

For general information, the output of this group in Contract Year 1963 conslsted of:

Average Pages

Per Docunent

12 monthly technical letter reports

12 monthly flscal reports

6 special reports on rellability

29 volumes of program plaming and replanning

3 volumes of final year-end reparts

93 special topical reports

$$
\begin{gathered}
220 \\
45 \\
200 \\
750-800 \\
500
\end{gathered}
$$

The above represents an average of three reports per week, all of substantial s1ze. There is no indication that the total reporting requirements w1Il be any less this year and leter, but will add the following requirement:

Quarterly Technical Reports

(Ia place of monthly)

450

Monthly Mlestone Reports

70

Monthly Rellability and

Quality Control Reports

200

Continuation of this service under the same work setup is considered essential to proper performance of Contract Item 4.

10. Time Fectors, Etc.:

Due to the fect that this room will be occupled by June 1964, accurate cost estimates, capital expenditure and requisition, etc. should be prepared without delay. Construction should begin irmediately, to allow documentation personnel adequate ofilce and working space by June.

11. Equipment Inventory on Fand:

Ceneral office equipment, 1.e., desks, cabinets, etc., Is available. Open shelving, 50 linear feet, will be needed. 
1. Irame of Bacility:

Drafting and Data Control Closed Areo

2. Neture of Fecility:

Drafting Area - Closed Area with drafting boards plus 2 small "banker's" offlces. Central Data Control Area - Closed Area with 6 small offlces. (Bee Appandix A for adaitional data.)

3. Pocuired Spece (Sg. Ft.):

5,900

4. Dyarings, Etc.:

See Appendix A.

5. Cost of Acquisition (Approx.):

$\$ 14,000$

6. Llumber of Personnel Assigned:

a. Drafting - Forty-six people are authorized for this function.

b. Date Control - Trelve people are authorlzed for this function.

T. Comizant Department:

Frofineering Services, P. Shaffer

8. Purpose:

Provide closed working area for draftsmen that w11l erable them to bandle at a mintmum dramings, charts, etc., thus increasing effective time, security regulations and productivity. Data Control area's purpose is microfilming, enginoering releases, effectivity control, vellum starage, microfilm developing and mounting and related blueprinting.

9. Contractual Requirement or Pollcy Development:

Since both of these functions are directly connected with contractual requirements, this discussion is limited to the desirability of a separate Closed Area.

The IUERVA security roquirements, while no more severe in theory than any other classifled project, are in practice unusualiy severe because of the bigh Irequency of Restricted Deta documents and dravings. REON is required by contract not only to generate drawings, but also to fllo and index drawings of all subcontractors, plus a large reference f1le of drawings of the LOs Alamos Sclent1flc Iaboratory, many of which are Confldential - Restricted Data, which require careful handiling because of security clearance and meed-to-know considerations. The easiegt way to assure proper protection of this large volume of 
C-RD material, both in work and in storege, is to restrict the aree in which the material is generated, processed and stored. With a Closed Area, it will be possible to leave classified drawinge in process on draving boards overnight, thereby making substantial savings in setup tims - up to 45 minutes per day per classifled drawing on the board.

Integration of drafting and data control functions is desirable because they are so olosely related in operation. Drewings are microfilmed on completion or recelpt from subcontractors. A Becordak viewer (ACC ormed) is avallable for quick reference, and a rented Xerox printer furntshes standard size prints for more extended use. This integrated function has provided excellent and rapid service to the project for about one year, and 1ts contimance will frellitate the bandiling, otorage and reproduction of drarlags. A blueprint machine has been requisitioned to permit check prints to be made evallable immedistely, to permit rapld distribution of prints of incoming vellums 80 that there can be maxtmum speed in responding to progrem requiremants, and for afflce-type reproduction of materials too large for office coplexs.

10. Tims Fectars, Etce:

These two combined areas should be ready for occupancy no later than Jume 1.

11. Equirment Inventory on Hand:

See Appandix A. 
1. Pame of Facility:

Uncleared Personnel Aree

2. Hature of Fac1lity:

Open area immediately outside the REON area

3. Required Spece (Sg. Ft.):

$1,000 \mathrm{sq} \cdot \mathrm{ft}$.

4. Drevinge, Etc.:

Not applicable. Any area directly outside the REON area will suffice.

5. Cost of Acoulsition (Approx.):

Should it be necessayy to wall off a proportion of a floor, otherwise a securdty area, for this purpose - \$2,000.

6. Inumber of Pexsonnel Assigmea:

Appraximately 20 to 40 pexsons w11l occups this area.

7. Comizant Dejartment:

Administrative Serv1ces, R. H. Harain

8. Purpose:

See Item 9.

9. Contractual Reguirement or Pollay Development:

Every person granted access to Restricted Data under the Atoric Bnergy Act must have a final, Governnent-granted clearanco. The processing and granting of such clearances or the reaffirmation of exlsting clearances takes substintial. amounts of time, and because clearances cannot be Initisted until a firm employmont agreement is made, it is inevitable that a number of poople will be "on board" In REON without having received clearances. 'They cannot be housed in the restricted RBON worls arec, but mst be placed In an open area set aside for this purpose. In oxder to have them at least pextially contributing while their clearances are being mocessed, a woris area adjacent to the REOIJ enciosure is virtually a necessity. This area constots of no more than floor space and desks. The location, hovever, is critical in tirat reasonable proximity mast exist between the uncleared people and thelr supervisors so that whatever wor's they can handle vithout secret clearance can be readily assigned and, on completion, delivered to superviston.

10. Time Factars, Euco:

Avallabllity of an uncleared area saould be nade no later than the date that a restirlcted ares is established for RBON. 
11. Equifment Inventory on lland:

Desks, chairs, etc. are not arailablo. Io additional equipment is foreseen. 


\section{Mame of Facllity:}

Finis Closed Area

2. Pature of Paclility:

Drafting boards butted as long work tables, magnetic boards on wall. Floorto-celling valls, 3-tumbler comblnation 10ck, closed security area.

3. Recuired Space (Sg. Ft.):

$800 \mathrm{gq} . \mathrm{ft}$.

4. Drawings, Etc.:

See Appendix A.

5. Cost of Acquisition (Aprox.):

$\$ 8,500$

6. Number of Personnel Assiened:

Eright emplorees are anticlpated to vork in this aree.

7. Cognizant Department:

Progaram Controls, J. S. Robbins

\section{Purpose:}

To provide a centralized area to prepare all PFRi functions and thus create the maxtmum effectiveness for whtch PIHRI was intended.

9. The PRRiP technique is a contractual callout. In REOH, as elsewhere under comparable requiremants, the best way of bandiling the PFRT operation Is to set aside a room adequate for the personnel assigned, with large wall space and drafting table capecity. The Closed Area requirement is desirable because it emables personnel to leave classifled material on the boards or valls, thus savIng the labor costs of securing varlous items during lunch time or at the end of the day. FERI charts, which are locked up; do not encourage essential interchange with vorking level engineering personnel. Charts on display contribute to an active process of upclating which encourages management use of the PFHRT tool. The room size requested has been tried at the Von Karman Center and found conducive to effective operations.

10. Tyme Foctors, Etc.:

This room vill be occupled by June 1964. Construction should begin immediately, to allow personnel to have adequate working spece by Jume 15. 
11. Equipment Inventory on Hand:

a. On Hand: Desks, magnetic boards, vellum cabinet

b. Heeded: If machetic boards are removed from present REON Von Karman Center PHRT Foom and shipped to Sacramento, only equipment needed is "Spert" boards. 
1. Hame of Fecility:

REOW Technical Information Center (FuIC) with open shelf C-RD storage

2. Fature of Paclisty:

Consists of a valut (floor-to-celling walls, 3-tumbler combination lock door, closed security area), open space behind service counter, and one offlce.

3. Required Space (Sq. Ft.):

$2,000 \mathrm{sq} \cdot \mathrm{ft}$.

4. Drantans, Etco:

See Appenaix A.

5. Cost of Acquisition (Approx.):

$\$ 6,500$

6. Humber of Parsonnel Asstmed:

Approximately twelve people will be in this facllity.

T. Comizant Dorartment

Adminlstrative Services, R. H. Inain

8. Purpose:

Used as a center for norling documents, classifled and unclassifled, used In IJHRA Besearch and Developmant. Controls security, secures materials, catalogs, and Indesses them, control of reproduction, etc.

9. Contrectial Regulrement or Policy Dovelorment:

This function is a natural outgrowth of various procedures connected with security, cubmission of reports to customer and otherr, and library and other information media.

The IIHRVA program requiles a wide range of reports, documents, books and other materials to bring information on applicable technology and related program proceress. These materials are for the most part classifled, in constant ves, and must be immediately avallable. Approsimately 100 requests for information are bandled each day. At Secramento this activity will be furtber expanded to ensompass REOAI centrel records. This function requires open-sinelf, vault storage for classifled documents; woriding ares for cataloguing, indexing and making searches; faclilties for rrapping; ares for retrieval equipment; area for englneers to review documents (thereby avolaing large automatic distribution); and area for necessary gocurity activities. 


\section{Time Pactors, Etc.:}

AII construction and modifleations are to be completed no later then 1 June 1964.

11. Egut posent Inventony on Hand:

a. On fland: Sbelving, classifled storag cabinets, desks, tables, anall verlfax, vellum cablnats, tub flles

b. Ireeded: Additional shelving, replacements for present unmovable counters, Jonlers aperture drilling equipment, keypunch-typesriter equipient 
1. Trme of Factitty:

Conference Rocuns (three)

2. Patwre of Facility:

Conference Room 1 - Floor-to-celling wells. Room to contain a 9-foot(Classified) diareter table, 21 chalrs, and projection equipment booth and screen

Conference Room 2 - Elght-foot-high walls to form a rectangular room that (Unclassifled) contains a 5-foot table and 20 upholstered chairs

Conference Room 3 - Floor-to-celling walls with accordion partition (Classifled) capable of dividing the room wben required. Contains 5 tables (one 5', one 6', and three 8 $^{\prime}$ ) and 30 chairs.

3. Bequired Space (Sq. Ft.):

Conference Room $1-360$

\begin{tabular}{lll} 
" & $2-320$ \\
& & -300 \\
\hline
\end{tabular}

Total 1480

4. Drawings, Etc.:

See Appendix A.

5. Cost of Acquisition (Apyeax.):

$\$ 5,000$ (all three)

6. Number of Personnel Assigmed:

Iot applicable

7. Cognizant Depertment

Administrative Sexvices, R. Ho hardin/Customer Relations

8. Purpose:

Conference Rooms within the ReON area are desirable because of the classifled material constantly being discussed at the majority of the meetings.

9. Contractual Requireront or Policy Development:

Bulsting conference roons are in use $80 \%$ of the time. Control of Restricted Data material discussed makes provision of conference space vithin REON area essential. The roons should be capable of being opened into one room for large meatings. 
10. Thme Factors, Ftc.:

Confexence Rocm should be available by 1 June 1964.

11. Eouipment Inventory on Iand:

Some equipment for the conference rooms (Bee paragraph 2 above) is on hand. Five additional tables and 30 chalrs are needed for Conference Rocms 2 and 3. 
1. Finge of Facility:

Iobbles and Accoss Control Cates (2)

2. Inture of Pacility:

Cate 1 - Counter Perimzter, Security Desk and Cate

Cate 2 - Security Desk and Cate with small counter

3. Required Srece (Bgo It.):

Cate 1 - $300 \mathrm{~Bq}$. It.

Cate $2-65$ sq. ft.

4. Dranings, Etc.:

Soe Appenaix A.

5. Cost of Acquisition (Appros.)

$\$ 2, \infty 00$

6. Number of Fersonnel Assigned:

Two gate attendants (one for cach gate)

7. Comizant Derartment:

Administrative Services, R. H. Hardin

\section{Purpose:}

ifo control access to the RFOIf area. Gate 1 will be constructed so as to provide a waiting area for escorts, new applicants, vendors, etc. Cate 2 will be for access only.

\section{Contractual Requirement or Policy Development:}

Because of the nature of the INGRVA contract, most material within the REON area is of such classiflcation that to obtain access, a final Government-granted clearance and a need-to-knor must be established. Therefore, control gates are mandatory to assure that only those persons who are properly 1dentified, escorted, etc. win access to the REOH area.

10. Time Factors, Etce:

Control gates should be constructed simultaneously with construction of the entire REOIJ area.

11. Equipment Inventory on Iand:

All equilment to furrish these gates is available and on havd. 
1. Name of Facil1ty:

Na11, Stationery supply Dlstribution Oeflce, and opflce Copying Center

2. Fature of Faclilty:

Boproduction equipment and complete mall accumulstion and distribution faclilty, staraze and distribution of standard supplies secured from plant statlonery stares.

Two connected rooms with 8-foot high walls

3. Recuired Spece (Sq. Ft.):

$350 \mathrm{sq} \cdot \mathrm{et}$.

4. Exaringes, Etc.:

See Appendix A.

5. Cost of Acquisition (Aprox.):

$\$ 2,000$

6. Humber of Personnel Assigned:

FIvo

T. Comizant Department:

Adminlotrative Services, R. Ho lardin

B. Purpose:

This faclitty supplies all RBON personnel utth necescary stationeny supplles vithout delay usually Incurrod when ordering from Von Karmen Centor Stationery Stores. Tho center provides fast and efflclent delivery of all internal correspondence, Incoming U.S. mall and inconing IWX'es. The reproduction facility saves time and money for all personnel in that materlal is reproduced in a local, convenient facility.

9. Contractual Requirement or Pollar Develojment:

The s1ze of the REON rpoject orennization and the falrly heavy volume of Incoming and outgolng mail and internal memos make it desirable to have a mail facllity integral with the project. Simflarly, the usage of more comm iteme of stationexy makes it econonilenlly desirable to stock such items in a convenient location. 'ine same condition prevalis in the matter of reproduction fecilities. Both pail distribution and reproduction are closely tied in with correspondence control to assure timsly action and response. As practiced for the jest three years, the consolidation of the above three service functions Into one area, staffed by one smill eroup, has made it possible to maintain 
adequate service in each area vithout unnecessary cost since the persomel assioned to these functions perform them as required on an interchangeable basis. Truss, when the mall is "recelved," It is promptly sorted into the apgroperiate plopon-holes, and the sorter is free to service the oupplies ar offlce copiers. Since the latter are nocmally in use on a full-shift basis, the net effect is that the mall and stores function. 1s. a lor-cost 1tem. If these services rese not thus functionaliy and physically cambined, the service would have to be performed at a probably higher cost.

The combination of these functions malos possible the mainterance of high-caliber service in those and othar functions at a 10 cost because alternative rork loads are always avallable should vork on one function become slack.

10. Time Frators, Ftc.:

The reproduction center should be functioning at Sacramento as soon as possible. Jume 15 the trangfer of personnel should be coungleted and the center must have facilities, supplies and equipment ready to resums service.

\section{Eoutument Imrentory on Hand:}

Statlonery shelving, ditto, Verifax, and Thermofar machines are RwON's property. The texox machine is rented as an overbead item. Xerox machino v17l bo ordered. 
1. Ham of Pacility:

Crynto + WX noom

2. Irature of Faclitty:

Floor-to-celling, soundproof room, with copper or lead shielding

3. Required Space (Sg. Ft.):

$120 \mathrm{sq} \cdot$ ft. $(10 \times 12)$

4. Drantinge, Etc.:

Bee Appendix A.

5. Cost of Acquisition (Apreas.):

$\$ 2,500$

6. Ilumber of Forsonnel Assiened:

One person will be assigmed to this area.

7. Comizant Departmant:

Administrative Services, R. If. Ilardin

8. Purpose:

io transmit classified material from REOIJ to the customar in a minimum amount of time.

9. Contractual Requiremant or Pollor Development:

inis requirement is a natural outgrowth of varlous procedures connected with security and the timely submission and handilng of classifled data and reports.

10. Hime Bactorg, Etce:

Construction should begdn whonever possible; or upon notiflcation by REOH.

11. Eguipnent Inventory on Fand:

All equipment required for this facllity is avallable except crypto termInal equipmont (sarambling device and tolotype machino) for uhich a capital Requisition 1s being prepared. 


\section{Hams of Bactilty:}

Managemant Control Center

\section{Pature of Faclitity:}

Spectal chart board display cabinets, special charts and conference tables, projection equipment and wosicroom for up-to-date mainterance of charts. Flocrto-colling valls, security door. This area vill be a closed security area.

3. Boputred Space (Sg. It.):

1,750 sq. Pt.

4. Drautings, Etc.:

See Appendix A.

5. Cost of Acquistition (Approx.):

$\$ 15,300$

6. Ihmber of Personnel Avolimed:

Fhere will be two people located in the Ifunsgement control Center and space for a rork area for up-to-date maintenance of charts.

7. Cofmizant Department:

Progress Evaluation

\section{Purpose:}

For use by REOH managers to mest for discusalons and plaming of various tasks on the llikRVA progaram. This room will house charts, eraphs, progrems, interfacing detalis and otber material for management use on a permanent display basis. Contimuous management exposime is a bastc part of its use. Closensss, corventence, and adequacy are mandatory.

\section{Contractual Reoulrement or Follar Dovelormont:}

Cumpently development of management control roons is being actively pursued at Corporate, Plant and major project levels in Aerojet. REFor manngement bas been directly involved in such planning, and with Admiral Baborn visited the Plavy Spectal Projects /anagement Center and Iockbeed, Sunnyvale, to got direct orientation on the use of such facllities on the Polaris program. since that time, REON manegement has reflected the high priority glven to this activity and has directed that immediate steps be taken to provide a outtable contrel room. A control $x 00 \mathrm{~m}$ is now in existence in REON, housed in temporery quarters in a conference rocm. Although the construction of a sultable control room has not yet been accomplished because of the REON move, it has high priority. 
Ir. J. J. 8. Daniel, formarly of Admiral Paboun's stafe, has been transferred to REOS to assume responsibility for the Progaram Analysis activity of which management control is a part.

It Is essential that the REON Management Center be in the vicinity of the Program Panagex and his principal staff members. The center's accossibillty should encourage top management to use and visit the room dally and thereby bring contimuousiy to top management's attention trends and problem areas which require management's attention and action.

10. Time Fectors, Etce:

This facility should be ready for occupancy Imodiately after the REDir move. Construction of the REDN area in Sacramento should Include this faclilty. The activity will be set up in interim quaxters pending completion of construct1on.

11. Equirment Inventory on Iand:

See Appenalx A. 
1. Inme of Eaclitiy:

siro Customar Office

2. Fature of Facility:

Trmee offlces, Plock-to-celling, plus a conference rocm

(See Appendix A.)

3. Bapuired space (Sg. Fto):

$563 \mathrm{sq}$. ft.

4. Denings, Etc.:

See Appendix A.

5. Cost of Acquistition (Appeas.):

$\$ 5,000$

6. Inumber of Percomiel Assimped:

Six custcmer personnel will occupy this office by June 1964. There is a possibility of expansion of one or two people beyond the six that are forecast in June.

T. Cognieant Department:

Hot applicable

8. Puspose:

To provide the customer resident with sultable offlce space.

9. Contrectural Requirement or Pollor Develorment:

It has been serojet's custom to provide the various customer resident offices in the past and RrON is adopting this policy.

10. Time Factors, Etc.:

Because of the fact that this roos w111 be occupied by June 1964, accurate cost estimates, capital expenditure and requisition, etc. should be prepared uithout delay. Construction should begln imediately, to allon sIrPO-C Resident adequate offlce space by June.

11. Ionizement Inventory on Ifond:

All pecessary equipment adequately to furnish these offlces will be purchased and supplied by June 1964. A detalled 118t v1ll be provided at a later time. 
1. Hame of Facllity:

Ceneral storage Room

2. Inture of Fac1lity:

One room connecting to mall area; walls, 8-foot high

3. Prouired Bpace (Sg. Ft.):

$400 \mathrm{sq}$. ft.

4. Dravings, Etco:

See Appondix A.

50 Cost of Acquisition (Apprax.):

$\$ 500$

6. Pumber of Persomel Assimed:

Hot applicable

7. Cogmizant Depertment:

Adminiatrative Services, R. H. lardin

8. Purpose:

To provide means of (1) storing bulky departmental material out of departmontal areas, (2) storing REON propenty not immodistely needed prifor to use or turn In, and (3) storing REON property used only intermittently (such as chart carr Lers, stepladalers, easels, etc.).

\section{Contractual Requipement or Pollicy Development:}

Storaze area will assist in keeping the REOI area neat, in accordance with Aerojet's good houselseeping pollcy. If mecessary, an area adjecent to the thoproduction center could be utilized for this facility, but storage should be by the Reproduction Center so that the material stored could be arranged neatly and access could be controlled.

10. Time Factors, Etc.:

This storeme area should be provlded at Sacramento as soon as possible. The transfer of pexsonnel should be completed by June 15 and the aree must be avallable for storage purposes.

11. Extizment Inventary on Hand: vided。

Equipment required will be shelving and bins. Speclflcations uill be pro. 
D. SPRCIAL AREAS

Spectal areas in the Sacramanto Flant fabrication and test facilities include the following:

Classifled Bardiare Vault

Xg Mockup Work Area

Assembly Area

Restricted if Area

Barchare Storege - Dest Stand Area

Data Reduction Center in CeH Area

Analog Computer - Instrumentation and Controls Iaboratory

Ilote: Capital expenilture estimatos are included in Soction V - Fiscal, Thble III. 
1. Hame of Facility:

Classifled Bardware Vault

2. Mature of Fac1lity:

A closed area with doublo doors which is accessible to fork lifts

3. Pequired Spece (Sq. Fto):

$300 \mathrm{sq}$. ft.

4. Drawings, Etco:

Iayout of the vault is not criticel.

5. Cost of Acouia1t1on (Appros.):

$\$ 1,000$

6. Mumber of Personnel Assigned:

Hone; for storage only, Personnel will not be assigned to ares.

7. Cognizant Department:

Administrative Services, Ro H. Hardin

\section{Purpose:} matertal.

Provide closed security area for stcrage of clasolfled, accountable

9. Contractual Requirement or Pallay Developnent:

Classifled, accountable materlal must be stored so that casual, visual observation may not be jermitted. The ralls mist be flock-tomcelling and the door must be locked with a 3-tumbler combination lock.

10. Time Factors, Etco:

A classifled hardure lault should be avallable by $15 \mathrm{lay} 1964$.

11. Equipment Inventomy on Inand:

lio equipment is on hand. A Iintted amount of shelving ulil be required. 
1. Pame of Facilitys:

XE Hockup Fonk Aree

2. Houre of Bec111ty:

One moclanp rowk area for XF Hoclax, nominally 25 at $x 30 \mathrm{ft}$, with 5 -ton overbead crans having hools beight of $30 \mathrm{ft}$.

3. Ropuised Epace (Sg. Ft.):

T50 sq. It.

4. Desolinas, Etco:

seo Appenasx A.

5. Cost of Acquistition (Amprox.):

Space only (See Item 9.)

6. Humber of Porsonnel Assimad:

Not applicable at present

T. Comprente Department:

Project Ingineering, P. Rowe

8. Puxpose:

Bee Item 9.

9. Contractual Requirement or Policy Development:

This is listed for planning purposes only, since the customer has not accepted our proposals to furnish the rockup; hotever, since we bave recently proposed it and expect an answer shortly, our planning should include space allocation roasonsbly coscurrent with the rent of the assembly vork.

10. IIm Factors, Btca:

IJot applicable at this time

11. Equipment Inventosy on Fand:

All equipment v1ll have to be suppliod. A detailad list vill be fuxulshed when accoptanco by the customer is evident. 


\section{Lame of Facility:}

Assembly Area (secured area)

\section{Patare of Protilty:}

The assembly area will have a bonded area for spare parts and asecmbly storage, haxdware stores, a tool crib, purw assembly stations, engins assembly stands, nozzle sssembly stations, support equipmant assenbly area, and a bot shop for sadicactive parts.

\section{Bequired spece (Bg. Fto):}

4,000 ag. ft.

4. Destings, Eto.:

INot applicable - to be furnished at a Iater time

5. Cost of Acquisition (Apmax.):

Hot avallable at thls tima

6. Humber of Bexsomel Ass1mad:

Hot applicable

7. Complant Dopartmont:

Project Engtreering, R. Rowe

8. Purpoge:

To provide for the antlelpated parts from outside production or from the Sacramento Plant mameacturing shops which will Plon into the asecmbly ares for final assembiy, scceptance test and shipwent.

The "IDt Shop" is a necessary and peculair JiGkA requirement. Its funotion is to poovide facijitiles as necessary to repair and modify contaminated ensine parts and to prepare activated anules for material analysis.

\section{Contractual Beculrement or Follcy Dovelormant:}

The Assembly Aroa is under direct oupervision of the IHRVA Acsembly Departmant and will paintain a bonded area for cyare parts and assembly otorege. Ifrdvare stores and tool crib functions are adaitional responsibllities.

10. Time Factors, Ittc:

Completion of this facility will be required by 15 Dacember 1964. During Contract Year 1965, this aspembly area is required for performing abovementioned dutios. 


\section{Eoutronent Inventory on Fand:}

Ilot applicable at present

A detailed list of equipment needed or avnilable will be furnished at a Iater date. 
1. Mame of Factilty:

Area "H" Bestricted Area (Fencing)

2. Mature of Facility:

A o1x-foot-ixicin feuwe 1,200 feet long around rost stand "H"

3. Recutred Srace (8q. Fto):

Hot applicable

4. Dranings, Etco:

ILt applicable

5. Cost of Acoulisition (Aprocos.):

$\$ 3,000$

6. Tumiber of Personnol Ass1smed:

Iot applicable

7. Comizent Dopartment:

llot applicable

8. Punnoge:

To prohibit Visual or phrsical access into the Test stand "H" area

9. Contrectual Feoulrement or Folior Dovelorment:

Classiflod nature of the bardrare boing tosted mecosaltates such a fonce around the test area.

10. The Toctors, Btce:

Construction of this fence should begin as scon as poselblo. All necescary adminlotrative dutios w1Il be initlated immodiately.

11. Eouirmant Inventory on Fand:

IJot applicable 
1. Ham of Facilitar:

Hurdurare Storage: Thest Stand Area

2. Hatume of Pactility:

Tho store areas will be required which can be secured.

3. Peoutred Space (sq. It.):

1,600 sq. ft. (two 800 sq. ft. areas)

4. Drawinge, Etce:

Layout of the two areas is not coritical.

5. Cost of Acoulstition (Apporox.):

$\$ 5,000$

6. Humber of Peroonnel Assirned:

No personnel will be assignod to these areas.

7. Comizant Departmant:

Englnoering support, D. Holaman

3. Purpose:

Storage of hardirare adjecent to tast stands

9. Contractual Reouiremant or Pollay Devolopment:

Bpace is required to store haxdware before, during and after tests are zun. Classifled hardurare must not be left where caourl, viewal observation is posatblo.

10. Time Factors, Etce:

These areas should be avallable no later than $1 \mathrm{July} 1964$.

11. Equipment Imventory on Hand:

Tais is a new requiremont; therefore, some abelving vill be required plus a suttable enclosure. 
1. Inme of Pactilty:

Date Reduction Center for CSII Area and IriO Injut 
1. Hame of Pactiltex:

Analog Computer Faclilty, Instrumentation and Controls Iaboratory

2. Misture of Factility

Fuollity to be six rooms, totaling 8,000 sq. ft., for the follouing:

Tranaducer Laboratory

Actuator Test Fecility

Computer Laboratory

Couputer Leinterance

Hectronics Iaboratory

Rewote Control Mockups and Admintstarative and Euparvialon Axea

3. Requirad spece (Sq. Ft.):

$8,000 \mathrm{sq} \cdot \mathrm{ft}$.

4. Draminas, Bre.:

Boe Apreandix A.

5. Cost of Acquialtion (Axpose):

$\$ 100,000$

6. Mumer of Pexsonnel Aggigmed:

inere will bo twenty people on hand in the Immodiate area of the laboratany.

7. Cognigant Dorartmont:

Instarmentation and Contrals, H. Lo Irvino, Hanager

8. Purpose:

The controls problem on the IrivVA engine is the creation of a aystem of senscrs and information prosessing which will be able to talo information axising from openating phenoman, analvze it, and apply it to activation or adjustment of controls (pumpe, ralves, and muclear coutrols) toward desired ongine pexformance. The situation differs from normal rochet engines in the aheer couplextity of phenomena; cyrogentc to extremely high temperatures, use of Iiquid bydrogen which poses problems of purres, seals, corroston and htaph volatility; a highly radicactive environment which produces radiation damags and heating, and much longer zun duration which makes neceseary and permits use of a courwehensive, sophistlcated, and carefuliy balanced feedback system for control. 
The develogment of the system requires the development of senscres which are capable of measuring the extrems values to be used for contral purposes, the cellibution of the sensors and other components 80 that their behavion In this couplex and excotic environmont can be reliably lenom in advance, and the aspeabily and testing of all components together so that their operation as a syrtem is predictable, their intersetions $k$ morm, and noeded modiflcations and devalogwent can tals plece. In this effort, the apalog computer is utillised to stmulate a miseing plece or aystem of the engine 80 that the aystem can operate as a unit during the component developmant effort.

\section{Contractual Bopulremont or Polser Direlormant:}

These labcratcreles ere neceseary to perform the contractual comnitmente Ior the dovelopment, asgembly, chockout and fabrlostion of transducers (part1oularly contral transducers) under sub-subtasis 2.4.6, and to perform control system evaluation by the tie-in af control syotem anpliflers and actuators vith the analog computer stmulation of the engins and test stand stmalation. 'ints trask is dons under sub-subtasies 1.5.1, 1.5.2, and 1.5.3. Additional needs are stated under sub-subtask 2.2 .8 of the How statoment: "Uperade the design criterle for the test simulator; uprade the test stand control system functional requirements and design critersia."

10. THms Factors, Ftc.:

The Contrals Ioboratory Fecllities should be made avaliable as socn as possible but not Iater than 30 Septeriber 1964. While the spectefle requirewents Ior the engine control aystem have been deleted by the custoner for the remainder of this coutrect year, they will be reinstated for CY 2965 and CI 1966. CI 1965 begfins October 1.

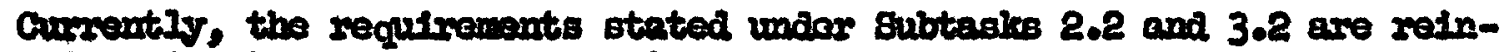
stated Immadistely and the rock vill be conducted at the Armsa factilties.

11. Exulpment Imantory on Find:

a. Roufpwent on hand: Appendix B

b. Equipment noeded: Apponde c 


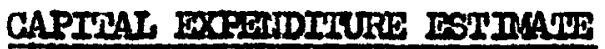

\begin{tabular}{|c|c|c|c|c|}
\hline Epectel Area & Sg. Fto & $\begin{array}{c}\text { Est. Cost } \\
-\$-\end{array}$ & \multicolumn{2}{|c|}{ Whan Heoded } \\
\hline Documentation Area $\checkmark$ & 1,600 & 6,500 & June & 1 \\
\hline Drafting and Inte Control Clobed Area & 5,900 & 24,000 & Juns & 1 \\
\hline Unoleared Personnel Ares $V$ & 1,000 & $2, \infty 00$ & June & 1 \\
\hline FaraP Closed Area $V$ & 800 & 8,500 & $\operatorname{Tun}$ & 1 \\
\hline REOed Techntesl Information Conter $V$ & 2,000 & 6,500 & Jume & 1 \\
\hline Conference Rocme, ROA $\checkmark$ & 1,480 & 5,000 & June & 1 \\
\hline Iobbies and Access Control cates (2) & 365 & 2,000 & rune & 1 \\
\hline $\begin{array}{l}\text { Inil, stationery supply Divtribution } \sqrt{ } \\
\text { Office, and offlce Copying Center }\end{array}$ & 350 & 2,000 & Juno & 1 \\
\hline Grypto IVX Rocm $V$ & 120 & 2,500 & Bept. & 1 \\
\hline Ifurament Coutrol center $V$ & 1,750 & 15,300 & Jume & 1 \\
\hline BIIPO Custamer aseico & 563 & 5,000 & June & 1 \\
\hline Ceneral storage Rocm (orf1ce) V & 400 & 500 & ASAP & \\
\hline Classiflod Ibretware Vault & 300 & 1,000 & $\mathbf{M} \mathbf{y}$ & 15 \\
\hline IE Aocianp Voris Area. & 750 & $\begin{array}{l}\text { (Space onity } \\
\text { at prosent) }\end{array}$ & Bept. & 15 \\
\hline Assembly Area & 4,000 & (Bpace only) & Dec. & 15 \\
\hline Area "H" Pectricted Aroa (Fencing) & $I / A$ & 3,000 & ARAP & \\
\hline Ilardirare storage: Test stand Area & 1,600 & 5,000 & Jury & 1 \\
\hline $\begin{array}{l}\text { Data Reduction Ceuter for Cell Areas } \\
\text { and nso Input }\end{array}$ & 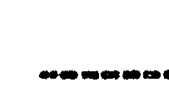 & Io be supplie & 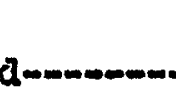 & $-\infty$ \\
\hline $\begin{array}{l}\text { Analog Computer Faclitity, Instrumen- } \\
\text { tation and Coutrols Inboratony }\end{array}$ & 8,000 & 100,000 & Oct. & 1 \\
\hline Storage for FX Moclap & & (Bpace only) & Sopt. & 1 \\
\hline
\end{tabular}


TABLE III - COIFID

Spectal Area

Hot shop

Capital Equipment

IHscellaneous

$\begin{array}{ccc}\text { Sa. Ft. } & \frac{\text { Eat. Cost }}{\text { Si- }} & \text { Mhen lleeded } \\ \text { Est. not yet avallable } & \text { ACC FY } 1965 \\ \text { IV A } & 39,500 & \text { As required } \\ & 10,000 & \text { June } 1\end{array}$

Sect1on IV, Page 40 


\begin{tabular}{|c|c|c|}
\hline & $\begin{array}{l}\text { Het Space } \\
\text { (sq. It.) }\end{array}$ & $\begin{array}{l}\text { Ihrmber of } \\
\text { RFFon Personnel }\end{array}$ \\
\hline 1. BNPO & 563 & -- \\
\hline 2. VAIIL & 190 & -- \\
\hline 3. Ploatimy & 65 & $-\infty$ \\
\hline 4. Documentation Services & 1,600 & 12 \\
\hline 5. PRRT & 800 & 8 \\
\hline 6. Access Contral & 545 & 3 \\
\hline 7. Nanament Contral center & 800 & 2 \\
\hline 8. Crypto ThX Room & 120 & 1 \\
\hline 9. Contracts & 1,500 & 15 \\
\hline $\begin{array}{l}\text { 10. Analog Computer Facility, } \\
\text { Instrumentetion and Controls Iaboretory }\end{array}$ & $8,000 *$ & 20 \\
\hline 11. Subcontrects & 2,000 & 20 \\
\hline 12. Date Contral Closed Area & 1,400 & 12 \\
\hline 13. REON Technteal Information Center & 2,000 & 12 \\
\hline $\begin{array}{l}\text { 14. Mail, stationery Suproly Dlstribution } \\
\text { Office, and Office Copying Conter }\end{array}$ & 350 & 5 \\
\hline 15. Drafting & 4,500 & 46 \\
\hline 16. Three Conference Rooins & 1,480 & - \\
\hline 17. Ofrices & 19,160 & 180 \\
\hline \multirow[t]{4}{*}{ Other Direct and Inditrect } & 21,645 & 333 \\
\hline & 66,713 & 67 \\
\hline & $-8,000 *$ & \\
\hline & 58,718 & \\
\hline
\end{tabular}

Hote: Does not InGlude aisles, lobbies, passagarays, restrooms, etc. 
V. FISCAT

RBow prepared a forecast for the Aerojet.Generul Corporation 1904 fiscal year. However, because of Imalnent cutbeclis in the grogrem and because of the posstble move to sacramento the forecast was not subiltted to the Corporate Capltal Bxpenditure Comalitee. On Lts ow initiet1vo the conditee established an authorization of $\$ 20,000$ for interim expenditures for itens of office equip. ment costing under $\$ 1,000$. Of this authorisation, arperoxirately $\$ 8,000$ has been oblicated.

The total forecast was for $\$ 93,000$. In alditicn, it had been acreed that the Von ICarman Center would ralie a special submiasion of approxdmately $\$ 100,000$ for an addition to existine bullalngs to house the crntrols laboratory, the latter faclilty to Include most of the items to be 1rcluded in the Instrumentation and Controls laboratory at sacramento. This special submission was also superseded by the decision to move REOAi?.

As the regult of the foregoine, the capltal buiget which w111 be oubmitted In the Imediate future will cover expenditures for the full flscal year and include anticipated costs arisinc out of moves of RDY personnel to Sacramento and Ias Vegas, as well as the Instrumentation and Corttrols Ieboratory and nomal operating needs.

ONIFEARAD BUDGIST:

A special study of the problem of tranoltion in the overhead bulizet and accountinc area is currently underway and will be corpleted so that Rrow input to the Sacremento plant way be provided for the Nay 15 due date. 
VI. SEXURTYY REAUTRTIIOANS

A. GEIERAT

A wajor secursty reguirenent for REow arlses from the pact that a larce proportion of the rateriel generated end handled on the program is classifled; that much of this material, because of its relationshtp to nuclear enercy, Is Restricted Data under the Atomic Frexcy Act of 1954; and that access to such unterial can be given only to those with a need-tosinow and a finel government granted clearance. Adaltional compilcations axise because pontions of the information in REor custoty were recelved or developed under ABC "Q" classiflcation and there continue to be "Q" vendors and "Q" sarociate orcanizations in the progran. There is "Q" information which would be vital in consideration of advanced nuclear xocliet systerns, and cextain "Q" Infoxwation 18 needed on at least one MBRVA task.

Of particulas security bignificance is the guantity of classifled matertal gublished by REOR. Table IV, RTON Classifled Information ING, IIsts the classifled raterial publiahed during June 1963.

Erch publication job requires clasalficetion declstons, pege by page; control of trsensmttal of classifled infosmation; authorizstions for reproduction; crestion of photos, offset and mult1lith masters, 11tho-negatives, etc.; establishrent of distribution 11st3, needuto-linow decibions, and effort for distribution, proper storage and sefecuarding, and vitimate destruction. All of these require Instructions, training, supervision, and controls.

HEon's imodiate moblem is the transfer of active classifled naterial from its custody in the Von Karman Center to its custody in the sacramento center. This tranafer is taling place concurrent with the transfer of restricted deta document sccomtablilty from the forrer mon wrensfer and Accountablilty Station to the Von Karman Center Master Document Control Center. Thus, assive records, consolidetion research, and recordseposting and reviaton job 18 teliting place whilo documents are being prepared for shipnent.

To wake the transfer, detalled steps are required which are outIned in the paragraphs following. In mumasys these roquire:

1. Pregaration of complete log sheets to cover each classifled document contained in a pacliage shipped.

2. Establiahment of REow control station regponelbility at Sacramento for recelpt and relosue of material shipped.

3. Establishment of qualifled becure holding place at Sacramento for Individual and REod Techntcal Information Center holdings of clessifled materials, to permit shipments of documents shlch vill not be required during the moverient period.

4. Recungtion of RIC sexvice at Sacremento. 
5. Istablishment of a $Q$ interest and a $Q$ facility and transfer of $Q$ docunents in Bifon custody thereto.

essential:

6. In adaition for operation at Sacranento the following are

Expor proper.

a. Eatablishment of a corpany-contzolled access ares for

b. Fatablishment of speclallzed closed areas as follows:

(1) Documentation fioon

(2) PRin Boom

(3) Rrow dechnical Information Center

(4) Banagement Control Centers

(5) Classifled Haxdware storage

c. Dstablishrent of company controlled access area.

(1) Areas $C$ and $\mathrm{I}$

(2) MERVA Assembly Ares

(3) Instrumentation and controls Iabosatoxy

i and $\mathbf{s}$ ).

d. Breperation of area access instructions (Appendices C, offlcials (sea attached).

C. Degignation of claselfication and group assignmang

seproduction.

f. Designation of those authoxized to apmove classifled

C. Desionstion of Becurity Representatives.

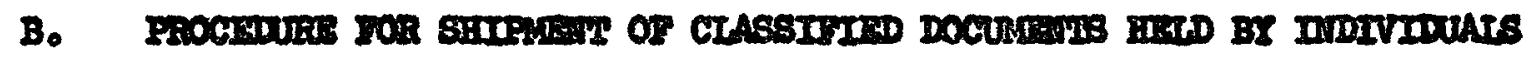

A mocedure has been prepered and distributed which outhines the steps to be talien for Inventory, bosing and transfor of classifled documents to Becramento and IIEN (Appendix I). accumalated.

Bosed documents are forwarded as soon as a shipment has been 


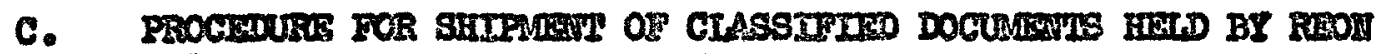

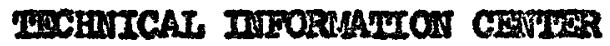

as follows:

1. Classifled docunents in RIIC will be prepered for shipment

a. Prepere inventory shoet in triplicate, listing documents in each box. Prepare ulling label. In duplloate. Place two coples of inventory and malling labels in box with documents. Mlie one copy of inventory.

b. Documents bosed for shipment will be checlsed by lDce at Von Karman Center against the inventory, the box sealed and wropped and forwarded to Sacramento, IDCC, attention firc as indicated on nallinc label.

\section{REORE COALIROL BNALIOA}

In the past, Plve Control Stations have been eatablished at Stcrem mento to process classifled documents for REoN personnel. These Control Station functions have been assicned to seczetarles. In the imediate future a swow Control Station w111 be establlahed and the previous stations w111 be elinfinated, except where geogrephlc location malses additional stations neceseary.

Bacramento is not now a Qmolessed faclilty. The first step in obtaining a $Q$ clearance 18 to establish an interest or need-to-linow for access to speciflc categories. Next would be establishment of a $Q$ ares for $Q$ flle storage and an area for reading. Then would come the request for Facility Clearance. Also regulved rould be the following:

1. Approval of spectfle file cabinets.

2. Obtaining Q clearance for each person having access to the socrot waterial. An I clearance is oufficient for confidential weterial.

3. Istabliabmont of the method of destruction of 8 material.

4. Boteblishment of an sproved meil channel, Including a $Q$ maling adaresg, and appointment of apecific persons to plci: up the masl.

\section{CONPAMY CONLEOTIND ACGRSS ARra}

A large portion of material generated and handled by row perroonnel Is classifled. Nost of this classifled material, beceuse of its relationship to muclear enercy, Is Restisicted Data under the Atomic Inercy Act of 1954.

Closed and Compeny Controlled Access Areas are necessary to enoble Brod personnel to wori: efflcientiy with classified information without rlsk of unauthorlzed pexsons heving access and to enable Ris to establish and raintein proper control over need-to-linor.

Agpendices $\dot{C}, D$, and $E$ are security procedures prepared for operation of the REor Security Area at Von Karman Center. 


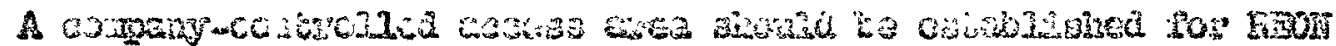

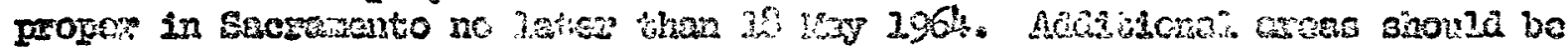

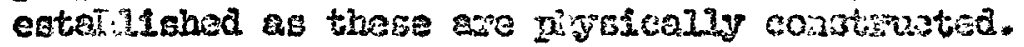

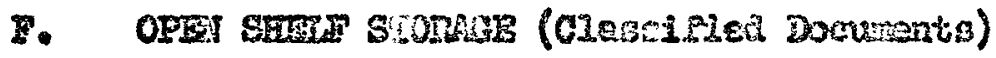

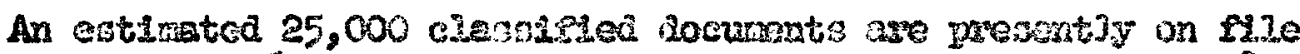

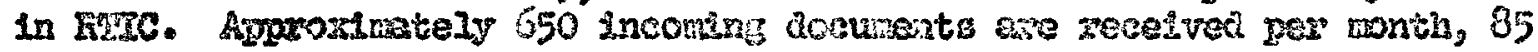

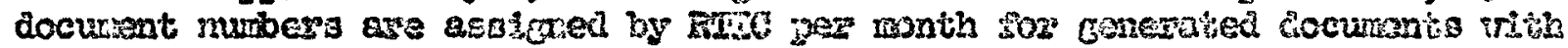

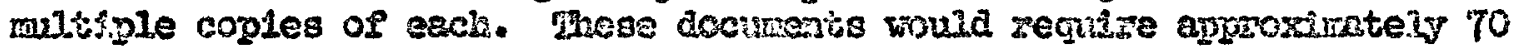
Pounduraver riles for etorege.

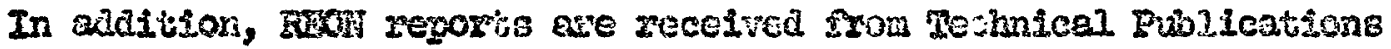

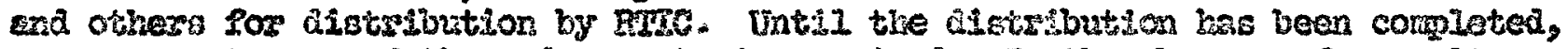

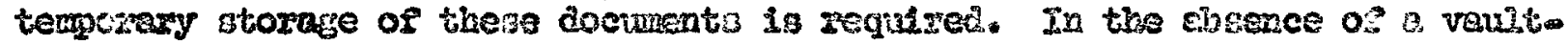
type gacility this would require fron 20 to $\$ 0$ fouredrewer inles be ricained

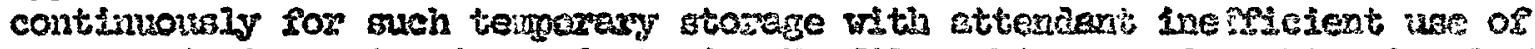
wgace and time. Opening and closing 70 file cebinets and conbinstion locls

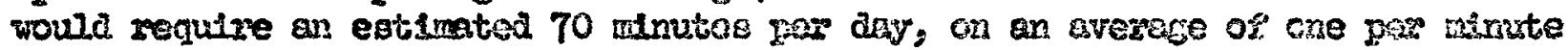

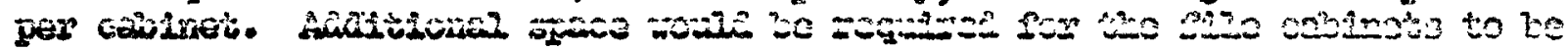
used for teuporaxy storege of documents. Floor lasding would be a problem with 70 to 100 ille cebinets concentrated in a small area. Firon already has shelving for a vaultetype operation and therefore, little alditional cost for shelving is sequired.

Because of the volume of docunents involved, the increased efficiency of operations, It is necersary that a Veult and Openeshelp storege be provided to store classifled docunents in PrIC. The vauit vould be deglgnated closed area.

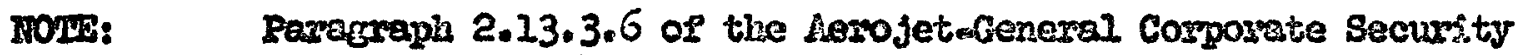
Mamual states that a closed aroa ney be used as an elternate method of storege.

At the present time, there is no space essigned in secremento to recelve and store bull material fros FuTC.

G. IESTHUTMON OF MATERTAT,

Present1y, clasaifled miteriel to be destroyed is collected and Cerifificates of Destruction axe prezered by BIIC personnel. Periodicaliv, these documents are forwerded to MDCC Por destruction. Ceatificates of

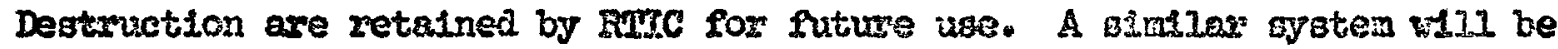
used in sacramento.

At present, when $Q$ moterial is to be destroyed, Certiplester of Destruction are mrepered by two Q-eleared pessons in Furce One parcon burns the documents and the othez is a vitness. Certificates of Destruction are retained by RIIC for future reference. A almiler axrangement ulli be esteblished in sacrenento. 


\section{H. DOCUREAT ACCOUNPABDTETY}

Secret and SPD Dociments are being assLgned AZ accountobility numbers and then recelved at Sacranento, rill be assigned $5 A$ numbers. Numbers assigned to Confidential and CRD documents will not be clanged at the present time.

\section{VISIT CLEARAITCES}

Because of the geographical alopersion of the MERTA Program, a great deal of travel is necessary. To permit required eccess to classifled information, visit clearances must be processed. During the kinon move it is not practicable to suppend trevel while security clearances are beling transferred from Von Karman Center to Sacremento. It w111, therefore, be necessary for spectel provisions to be made for advance processing of visit clearances out of Sacramento before the actual move has occumed.

\section{J. COURTER AUTHORTZAIIOAS}

RII has frequent need for courier authorleations. Although this is avolded whenever possible, tight deadines often necessitate that waterlal wast be hand carried to motings in Cleveland, Plttsburch, Hashington, etc. Ainost daily it is necessary to hand carry material to Poat Offlces and air. ports to assure recelpt on time. Fecllities sor arter-hours approvel of courlex authorlzations to meet the above requirenents are essential.

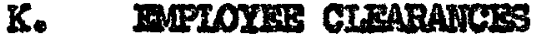

Before any employee can have access to Restricted Data he must have a final milltary clearance. For new erployees, processinc a clearence talies an average of three months. Reaffirmations of clearance taie from 10 days to two months.

Uncleared persons cennot be sdintted to the closed Areas (inthout escosts) and this delay in clearance is expensive in time and woney. Uncleared persons are able to work in the area set up for uncleared personnel; however, they are able to perform only a prection of the worls they will do later when cleared. The move to sacramento fill cause a major problem in the beginning until all new hires or trangfers have been cleared. The clexicel pexsonnel will be mostly affected.

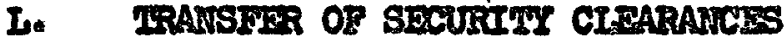

During the period that Brop personnel are raintaining offlces in both the Von Karman Center and Sacramento, securpity clearances will be reguired in both plents. A listing of all persons so involved vill be forwarded to sacramento to establish the cleerance there. On I June 1964, all clear. ances for Fron-VkC personnel will be transfexred to sackemento alonc ilth the transfer of the major nunbex of persons, exceptinc Rrois personnel remaining 


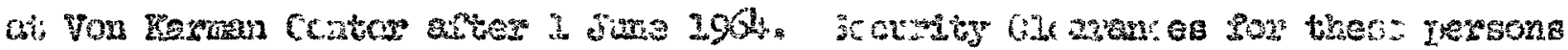

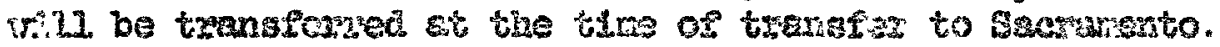

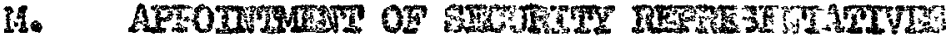

The Ruch Security coordinotor is the lannger, Administrative

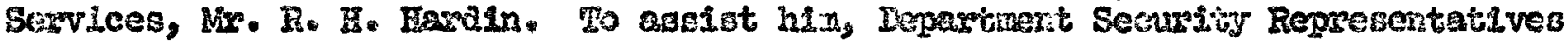
ara zequired. Rable IV is a list of security zepresentatives currentiy appointad.

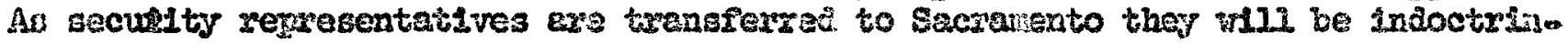
ated by representsitves of the Plant Security Manaros, Sarramento Plant.

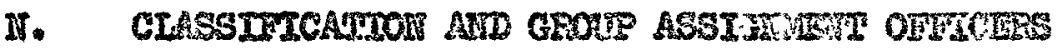

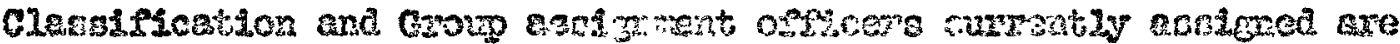
Ineluded in Table V.

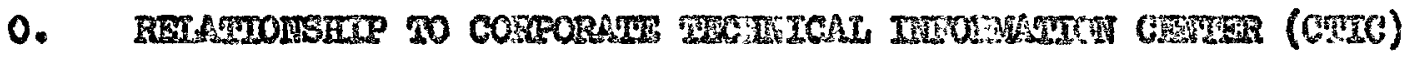

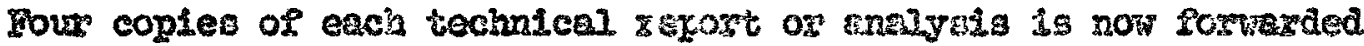

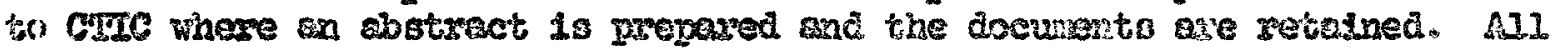
cissalfled material 18 maxised "Ifnited Distrubuthan" and secese is permitted only when a nesinto-linow has been estebilingd (Appendix C).

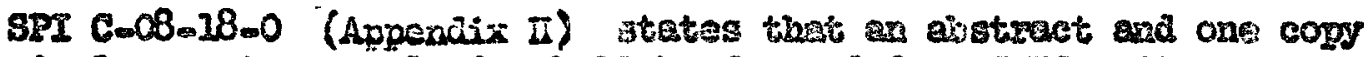
of each technicel report or enalybis shall be forwaxed to cric. At the present trine, Curc is mepering abatrests and foux coples of the docuntats are engreseded to CIrT.

It 13 expected that in the sutrse, each wathos will prepere abstracts III accordance vith the SPI. 
VII. consunrcamons

RIow has many and varied requirements for communications between the customer, subcontractors, and other Aerojet activites. This is mainly caused by the unueual conditions of operation within BIm.

The customer has an extromaly large organization to supervise the llwivA Project. Th1s larce stafl revlews, in minute detall, the operstions of Bror and subcontractors, which results in generation of many esncting requirements and in turn ceneration of frequent commications needs to and from Rros. At the preeent time, REN does not, within Itself, produce any hardware, but it does generate and recelve large amounts of paperworlt in its managemant of the In:iVA Progrem. Inls peperworli includes Bngineering Drawings, Speciflcations, Progress and status Reports of all linds. Hany of the reports generated by REON Include information received from subcontractors, ouch as Weatinghouse, and operations in $1 \mathrm{HO}^{\mathrm{O}}$. These reports cannot be finalized untll the information is recelved, revilewed, and assembled into the final report or other action by BroN. As a result, the last minute shipment of reports, etc., to the customer is the rule rather then the exception. Despite attempts to Irrmove the situstion, schedules established by the customar continue to be tight for both subcontractors and Blsor. A large proportion of River people are affected by the requitienents to forward such Itens within the deadines set. Usually, the iteins are ready for malling after regular worling hours and require special security handilng, and special handilng to get them to the asrport in time for scheduled flights.

Some rellef may be recelved in this area if crypto facsintle transe mission, for wilch our requirements have been sought by the Government, is Inotalled between Rrow and other activities.

Matlroom service 18 used to bring mall into and out of the plant on a soutine basls. Froir requires high quallty service in oxder to lreep delevs to a minions in recelving and forwarding

Telephone service to used extensively by Rrour personnel. Some 400 telephone instruments are presently in use in RsON.

An average of 330 TWKS are received and sent each wonth by Rwori personnel. TWXs must be handled by all concerned as expeditiously as positble. Any delay in receipt could meen lest deleys, fallure to meet deadines or other sexlous consequences.

Comminfeations are heavlegt betreen Raros and Cleveland and PIttsburg. Communications with Waghington, D.C. are gonswhat 1ess. Mall 18 used whenever instenteneous recelpt is not required. Telephone or TWX is used for Instantaneous cormanication but at present do not pentht discussion of classified inforcration.

At the present t1m, Aezojet almplane ilghts are made to and from Ias Vegas and Ontario on Mondeys and Fridays eech reeli. A simflar service will be required between Secramento and Ias Vegas. During the time when testing will be heavy at NTO, it will probebly be necessery to have one aircraft shceduled solely to transport REON and other NBRVA Project personnel to and from Nevada and direct commercial routing w1]l be neoded as well. 


\section{TABIE I}

(To be supplied) 
TABLE V

(To be Supplted) 


\section{TABLE VI}

(To Be Supplied) 
TABIE VII

(To Bo Supplied) 
IFIGURES 2 THROUGH 8 TO BE OFFSET 
Pigure 20

To be photo offaet 


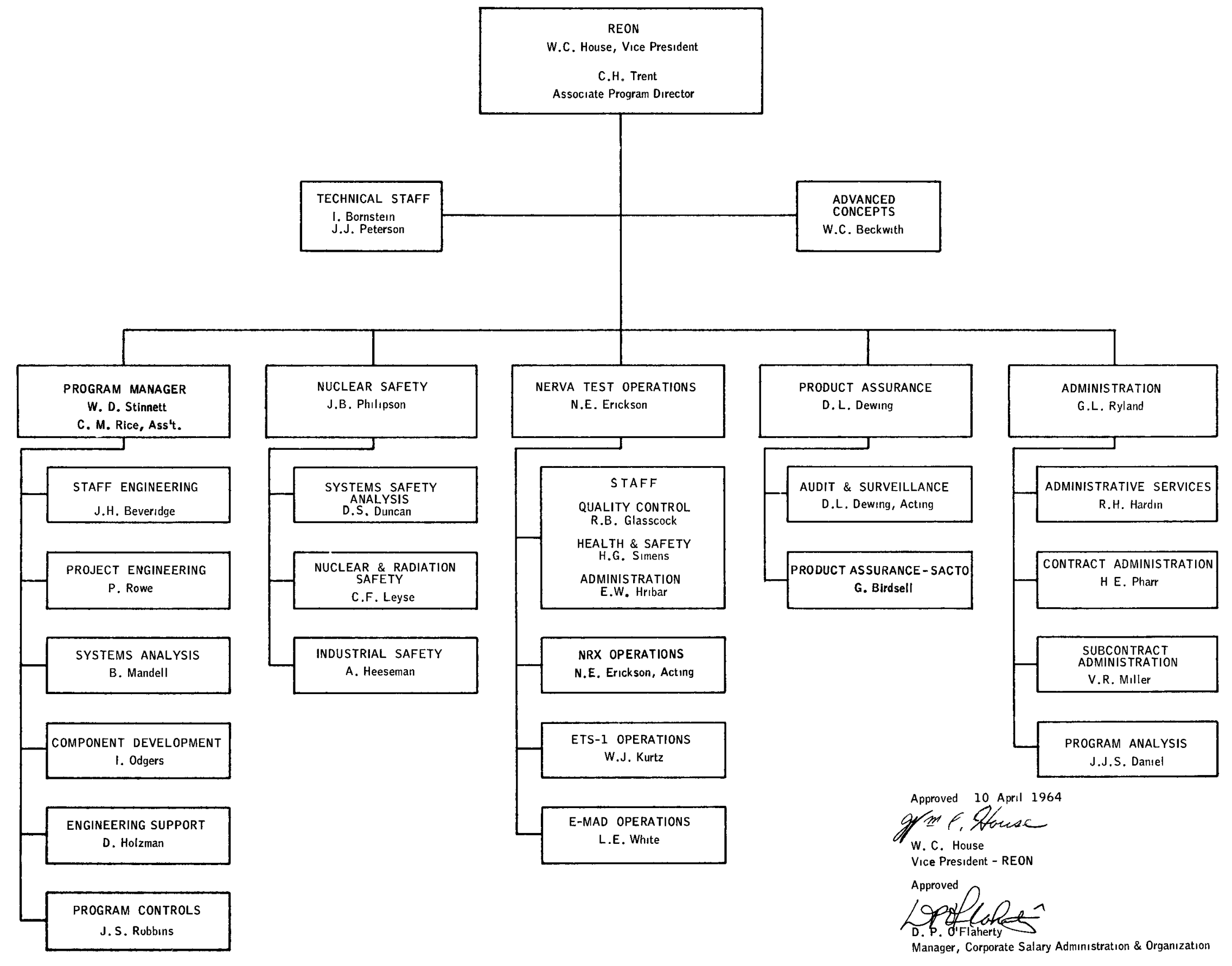



APPandices $A, B, G$ and $\mathrm{H}$ WIIl be offset 
A. Sort all docunents in your custody into four groups:

1. Docunents which can be destroyed.

2. Arrange with InIC for destruction of classified docunents in accurdance with AGC Sccurity Procedures.

b. Discard unclassified docunents. Fortard unclassified repurts to FIIC fur possible addition to the FIIC Library.

2. Unclessified docunents required.

a. Place docurents in file cabinet.

b. When documents are ready for shipuent to sacraisunto or NRDS, notify RIIC for FIIC check of file.

3. Classifled docursents required for use until moved to sacramentu or NRDS.

a. Place docunonts in rile fox use and safeguarding unt1l departure is about to be wade. (At that tine these will be processed as in 4 velow.)

4. Classified documents not required until after sacramento or NRDS muve.

a. Cunfidential and Confidential Restricted Data documents.

(1) Prepare inventory, in quadruplicate, and box docurents. (Inventory sheets availabie at RilC.)

(2) Place inventory with each box. Bach box will have inventory sheets wnly for documents contained therein.

(3) Prepare an appropriate wailing label, in duplicate, for cach box to be shipped as follows:

AEROJET-GITIERAL COIPORATION IDCC

Sacrassento, Califormia

or NERVA Test Operatiuns

AFROJET-GENTERAL CORPORATION

P.0. Bux 29T

Hercury, Nevada

Attention:

Attention:

(4) Docurnents boxed for shipucnt will be checked by IDCC at Vun Karrian Conter acainst the Inventory, tho box sealed and rrapped and forwarded to Sacrawento or NRDS, BDCC, Attention of person indicated on vailine label. 
Procedure fur lkivine Ducuroents

and Files to Sacrarantu or NRDS -2-

b. Secret and Secret Restricted Date Docuwents.

(1) Deteraine when you will need docuncnts in Sacrailento or IIRLS and advise RIIC.

(2) RRcturn docwnents to RIIC for processing shipment.

B. Iibrary Material

1. Retum all "Acrojet Library" reference books and reports on indefinite loan to the REON Unclassified Library.

2. Return all "Alerojet Library" naterial to the Von Kansan Center Main Livrary if it was not indicated as indefintte Ioan.

C. Shiment of Files to Sacramento

1. FUIC will check all unclassified vaterial in files, includinc desis file before shipinent.

2. FIIC will affix a "This Cabinet to be Used for Unclassified storage only" sticker, initialed by the checker, on each file when ready for shipunent.

3. All locks will be removed frow files before rewoval frum Building 160 and to vans. Locks will be returned to Lock \& Key Cuntrol.

4. Hocn files are ready for security inspection, FIIC w1Il notify IDCC for inspection and sealine of files. 
SECURITY CONIROL PAOCADURES

FRON FIESTRTCUES AREA - BUTHDTVE 160

1. Purpose:

1.1 To establish procedures for effecting securtty controls to cafeguard classifled Information in the Rroil Restricted Area in Buslaing 160.

2. Definitions:

2.1 Admitiance Control buployee - a properly cleared project enployee Tho has been Instructed in all phases of adittance control procedures and is assigned the responsib1ilty of effecting compliance.

2.2 Access List - A listing of the names of persomel baving a predetermined need-to-linow who regutre access to the area Infrequently.

2.3 Access Polnt - Any doorway or other opening which way be means of Gaining uneuthorized access to ares and/or information if not properiy securve, or aumbtance controlled.

2.4 Authorlzed Personnel - Properly Identifled personnel whose assigned tasis cannot be effectively accomplished unless access to the area 18 granted.

Hote: Individuals may be "author1zed" even though access to clessifled information is not suthorised, or required; proviaing they are continuously escorted by a responsible person, who assumes the responsibility of essuring there is no compromise of classifled information."

2.5 Intry Regleter a registar intalned at each entry for the purpose of recording the nane, time of entry and deperture, pexson visited, and puxpose of visit of persons entering tho do not heve " $M$ " badges.

2.6 Frequent Admittance - The reguirement for admittance to the area an average or tiree (3) days per veel:, for an indepinite period of time.

2.7 Ieed-to-Know - The requirement for access to Roil clessifled Information in the performance of assigned woxl:. A minimum clearance of SECRks (an interim clearance is not valid) is a prexequisite for establishing a noed-to-linow. 
2.8 Unauthorized Personnel - persons not properly identifled, not escorted shen one is required, or not requiring access to the area in the performance of their worli.

\section{Procedures:}

3.1

3.1 .1

3.1 .2

3.1 .3

3.1 .4

3.1 .5

3.1 .6

\section{Access Controls}

Forth and South Btalrway - a door with standard liey operated locleing hardvare will be installed at these locations and shall be locked when the area is unoccupied. An electrically controlled half-door or turnstile will be installed for controlling access durelng woriring hours. These otations w111 be manned by Admittance Control Buployees from 7:30 A.Mo to 5:00 P.M. on noxmal worising days, and during aw overtime shifts which exceed 30 percent of the total woxiling force of personnel aselgmed to the area. A lesser percentage vill reguire that each individual assume collolete responsibility for safeguarding information under his custody.

East Btaluray Door - Ints door w111 be Conspecuously marlied "Emergency Use Only" and shall be used only in an emengency. Door shall be mounted so that it opeas outrand from the Rlion area and shall have an emergency exit locls installed on the Inner side, and equipped for ikey opedation on the Inner side only.

\section{Horthrest Hall Door - (Bame as 3.1.2 above)}

West Center Hall Door - Consplcuously maxlied "Emergency Use Only". Houmted so tivat it opens outward from the Rrbor area and equipped with an emergency exit loci: installed on the Inner olde, operrable by liey from both sides.

Note: for the purposes of personnel trafflc controls this door will be considered an emercency extt only; however, 1ts use for moving equipment and materlal between Bullding $160 \mathrm{~A}$ and the frelight elevator is authorized. Any person opening thls docr shall be responsible for maintaining access conterols and for locling when purpose for openting has been accomplished.

Frelght Flevator - Cage doox on elevator will be equipped with a key padlock and shall be loclied when elevator is not in use.

Control of Keys to Peximeter Doors -

a. Jorth and South Doors - a liey for these doors will be retained at Gate $\# 3$ and way be iseved to any Azusa plant exployee having the area designator " $M^{\prime \prime}$ on his employee badge.

b. Brergency Doors and Blovator Door - A key to these doors w11l bo Issued to the Fron Stationery Stores offlce and Custodial Bervices offlce. Othes issuance of lieys to 
these doors w1Il require the prior approval of the lienacer of security.

3.2 Personnel Identifleation and Control

3.2.1 Project personnel and personnel of supporting activities of the Azusa plant who bave an establlshed need-to-now and require frequend adruttance shall be losued employee badges displayind the Aree access desicnator " 1 ". The Rrow Security Coordinator shall submit requests for the 1sguance of these badges to the Plant Security Offlce and shall provide notification when a chance of status occurs which elininates a further need for access to the Rrow ares.

3.2.2 Covernment and oubcontractor personnel, whose clearances and need-to-linow are vertfled, requirinc access on a frequent basis for an Indefinite perplof of time, shall be 1seued "Resident Representative" badces dimplaying the area access desicnetor "li". The REOH Security Coordinator shall oulunt requests and provide notification as in Paragraph 3.3.1.1.

3.2.3 A list of all other perzonnel, for whoin a need-to-inow has been eatabliahed, shall be maintained at each entry control point. The Manager of Security's approval will be obtained prior to placing a naxe on this 11st. Prior to pecrititinc entry to personnel in this catecory they shall sicm the ontry recloter and exchance thelr badge or pass for a "temporary $M$ " badje, and shall exchange the "termorary 14 " badge for their regular vadge or pass then departing.

3.2.4 Personnel whose nancs do not appear on the access 11st, but for whom a need-to-inow is established at tive of entry, shall sign the register and exchange badges as required in Para. craph 3.3.1.3.

3.2.5 Authorized personnel who do not have a need-tomlnow, 1.e., personnel who do not have the reguired clearance and/or do not require access to classified information in the performance of their assicned ror: mast sicn the reglister and an escort shall be in attendance pritor to perrittine then to proceed into the area. Personnel in this category must wear an "escort required" card throughout the duration of their visit and rast be continuously escorted wille within the area. Butry of personnel in this catecony must be iept to an absolute miniman.

3.3 Duties of Adut ttance Control Employee

3.3.1 Exployees assicned as adruttance Control Biployee shall be responstble for effecting coimliance as follows:

a. Shall assure duties at assigned station at the tine desicnated for comoncement of controls and shall rein 
continuously in attendance unt1l properly relieved or until time for discontinuance of elnteining access controls.

b. Shall establiob positive 1dentity and assure that rea quired identification is properly aisplayed preior to permitting entry intonthe area.

c. Shall permit no unauthorlzed person to enter.

d. Shall deteriline that an escort is in attendance when one is required.

e. Shall supervise entries in the Bntry Rectister agouring that all entries are completo, correct and lectble.

f. Shall maintain control of temporary " required" passes, recoverting all such badges or pesses Lsowed as the person departs.

C. Shall contact tire REDS Security Coordinator for culdance pertainind to any situation not covered by these procedures.

3.4 Documentation Area

3.4.1 Area shall be surrounded by floor to celling walls with no openinga which might peredt wauthorlzed visual or physical access.

3.4.2 Entry doar to the area shall be equipped for card-lsey operation when occupled and sinall be secured with a combination padiocl: then unoccupied.

3.5 I A A Station Shelf Storage Area

3.5.1 Area shall be ourrounded by Ploor to celling walls with no openings which micht perint uneuthorized visual or physical access.

3.5.2 Entry door will be secured with a combination padiocis when the I : A Station 1s not mained.

3.0 T \& A Station Woriting Area

3.ن̈.2 Durinc hours of operation access to this area will be controlled by electrically controlled halfodoors.

3.7 BPRT ROOD

3.7.1 Area sholl be surrounded by floor to ceiline weils with no opentucs which might perrat unauthorized visual or physical. access. 
Security Control Proceduras

Page 5.

3.7.2 Butry door will be secured with a combination padlocis when the room is unoccupied.

4. Security Coordinator Regponslb1lities

4.1 REDil security Coordinator shell be responsible for:

a. Instructing of all MEN personnel to the extent necessary to assure their beinc inotrledceeble of these procedures and of their individual responsibilities in effectins compliance.

v. Providinc copies of these procedures and current Access Ifists to eech Admittence Control Buployee

c. Submittind request to the plant securlty office for exployee badges requiring area access deslunator and for informing this offlce when any badges requested are no longer required.

d. Obtaining the ranager of Securlty's approval prior to placinic nawes on the Access Ifist.

e. General oupervision in all matters pertaining to security within the Brovi DAvision.

5. Deviations

5.1 Wo deviations to these procedures ofll be permitted without the prior approvel of this offlce.

6. All previous procedures and instructions pertaining to the security contiolis of the EIBOH Restricted Area are cancelled herewith.

C. A. Bowers

Hanager of Security

Azuca Plant 
TO:

AlI REDN Cate Receptionists

DAIE: 26 February 1464 $753: 850:$ BCA :EW

FFOM: REON Security Coordinator

SUBJEC: AccesB to REDN Area

The following procechres will be adhered to when processing personnel far admission into restricted areis at Rwow.

Non-Facort and Mon-Registered

1. ACC Personnel, w1th large "li" in . pper right hand corner of regular ACC (VKC) badgo.

2. WASA Resident Fepresentatives, when !HIItary bedge has large "If" in upper right-hand co 'ner.

Hon-Escont - Wat Ragister and Pick Up Access Bad:

1. AGC Parsomnel, as appear on approved 1: it.

2. SIro Fersonnel, as appear on approved 1.11..

3. Wajor sub-Contractors, as eppear on appuved 11at.

4. Consultants, as appear on approved list

Securlty, Plant Protection and Fire Section Personni.

1. The rames of personnel from these activ'ties in ed not appear on the access 11st. Identity and lo. 21 of clearance shall be confirmed when doubt existi.

Eecort Required - Lust Reglater and Plci Up Focort-Required Dg

1. All personnel, not on list, requiring access to the Rroy area. All pereonnel wat be under escort at all tlmes and not be in the area wore than $15-20$ aimutes.

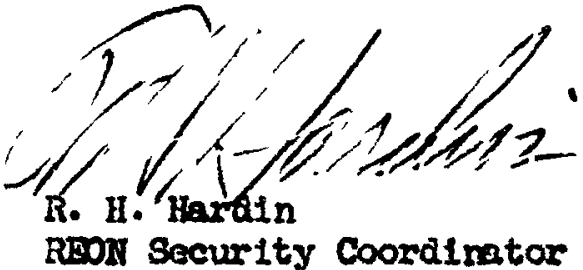

REON Socurity Coordirator 


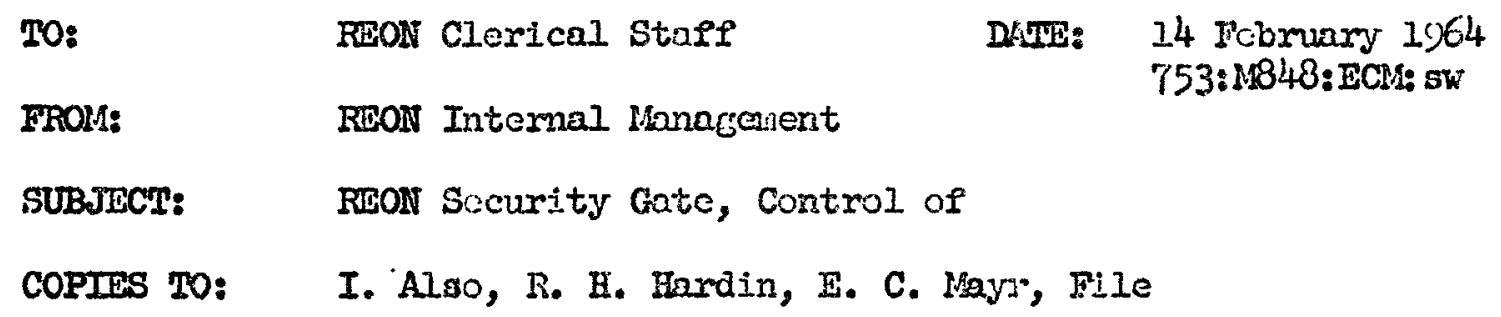

Due to the chance in clerical staff personnel, security cate attendants and their reliefs are now as follows:

Gate One (Main Lobby)

P. Hckonzie, Attendant $(8: 30-5: 00)$

Reliefs

$\begin{array}{lcl}\text { Early Shift } & 7: 30-8: 30 & \text { P. DiGennaro } \\ \text { Breals, A.M. } & 10: 00 & \text { L. Harding } \\ \text { Lunch } & 12: 30 & \text { M. Seynour } \\ \text { Break, P.M. } & 2: 30 & \text { L. Hardine }\end{array}$

Gate Tho (Rear Iobby)

V. Scott, Attcndant $(7: 30-4: 00)$

Reliefs

$\begin{array}{lll}\text { Bralak, A.H. } & 10: 00 & \text { A. Gorvanka } \\ \text { Lunch } & 12: 00 & \text { I. Kline } \\ \text { Break, P.H. } & 2: 30 & \text { A. Cervanta } \\ \text { Late Shift } & 4: 00-5: 00 & \text { J. Mason or } \\ & & \text { R. Viverto }\end{array}$

In the event person(s) are not avallable to relieve on a breais or for Iunch, they nay contact either S. Hilnot/L. Kline (for brealrs) or A. Cervanita/P. DiGunnaro (for lunch) tho are altemates.

This schedule will be strictly adhered to. Any prollons concemint

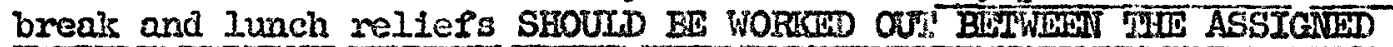

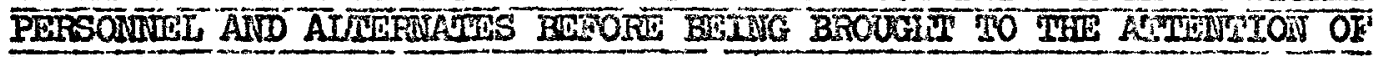
E. C. Dayr. 
This menorandul supersedes all previous weroranda concerning this subject.

Your cooperation in this watter is appreciated and will lead to a swoother security control of gates and personnel concerned.

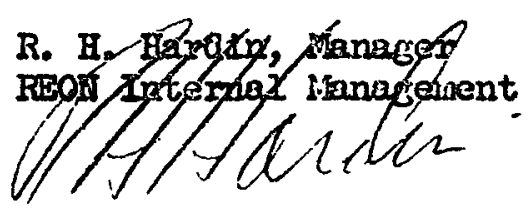

